\title{
Penerapan Aspek Rasionalitas Dalam Pemilu 2019 (Studi Terhadap Tingkat Partisipasi Politik ODGJ di Kabupaten Hulu Sungai Utara)
}

\author{
Budi Lesmana
}

suhu_rawa@yahoo.com

\begin{abstract}
Election as a means of popular sovereignty is a vehicle for every citizen who has the right to choose to use his political rights and voice in choosing a leader. Without exception, based on the provisions in the legislation, every citizen can use this right.

In the implementation of the 2019 Election, the KPU strives maximally to accommodate all citizens who have the right to vote in the DPT. Repairs made many times are as an effort to increase voter involvement in elections.

One voter group that is a public concern and discourse is mental accessibility or more commonly referred to as People with Mental Disorder (ODGJ) who voted in the 2019 election. Outside the context that these mentally ill people are under forgiveness according to civil law, the constitution itself basically gives the same rights to people who have mental illness to choose. Even in the Election Law itself there is no prohibition explicitly governing this. This means that mentally ill people also have the right to exercise their right to vote. Not all mentally ill people have the awareness to choose. Of course, if there are certain conditions that are allowed to choose.

But how is the implementation of the business and rules in the field as an effort to increase voter participation by the organizers? And what is important is whether the application of direct, general, free, confidential and fair election principles can also be felt by ODGJ voters. Can their rights be used, but only choose formalities without secrecy. Don't let the voting rights of citizens with certain conditions be given an opportunity to commit fraud in the election. Fraud is detrimental to the voting rights of people who have mental disorders because it is considered easy to be cheated.
\end{abstract}

Keywords: Elections, Mental Disability (ODGJ), Voting Rights, Participation. 


\section{BAB I \\ PENDAHULUAN}

\section{A. Latar Belakang}

Pemilu di satu sisi sebagai perwujudan kedaulatan rakyat dalam demokrasi dan rakyatlah yang memiliki peran untuk menjadikan momen ini sebagai wahana mewujudkan kedaulatan tersebut dengan melaksanakan pemilu yang bersih, jujur, adil dan bermartabat. Tapi pada sisi lain, ada situasi rakyat hanya sebagai alat legitimasi dengan tanpa pernah di berikan ruang untuk mendorong proses demokrasi yang partisipatif dan substansial. Karena saat ini semua proses hanya mengikuti proses administrasi dan prosedural semata.

Hal ini sebagai contoh adalah bahwa misal KPU masih banyak berkutat data DPT, karena banyak masyarakat yang belum terdaftar. Betul bahwa secara kuantitas rakyat harus ikut memilih, jangan sampai kehilangan hak. Namun pada hal substansi, rakyat hanya menerima apa yang ada. Terbatas ruang gerak hanya sekedar nanti ke bilik suara dan memilih. Habis. Jadi istilah partisipasi dengan kesadaran sendiri ini masih belum dapat terwujud. Yang terjadi adalah partisipasi yang di mobilisasi. Dan mobilisasinya butuh resources. Inilah yang lebih dominan muncul. Sehingga akhirnya rakyat sendiri terkesan abai pada hasil, apakah nanti yang terpilih bisa benar-benar sesuai dengan harapan. Orang yang terpilih memiliki komitmen dan integritas sebagai penerima mandat dan amanat.

Pemilu adalah mekanisme pemerintahan yang demokratis, karena wewenang pemerintahan hanya diperoleh atas persetujuan dari warga negara yang memilihnya. Secara universal pemilihan umum adalah lembaga sekaligus praktik politik yang memungkinkan terbentuknya sebuah pemerintahan perwakilan (representative goverment) yang menurut Dahl, merupakan gambaran ideal dan maksimal bagi suatu pemerintahan demokrasi di zaman modern (Robert A Dahl, 1992). ${ }^{1}$

Sementara itu Abdul Hakim: 1996, mengatakan Pemilu ditinjau dari perspektif Hak Asasi Manusia (HAM), Pemilu merupakan pelaksanaan hak dasar dan masa depan kehidupan bersama dalam suatu masyarakat. Selanjutnya, Michael Saward mengemukakan bahwa demokratisasi sebuah sistem memerlukan beberapa kondisi minimal seperti jaminan basic freedom (freedom of speech and expression, freedom of movement, freedom

\footnotetext{
${ }^{1}$ Pendapat Robert Dahl dikutip oleh Joko J Prihatmoko dalam buku "Pemilihan Kepala Daerah Langsung: Filosofi, Sistem dan Problem Penerapan di Indonesia”.
} 
of association, rights to equal treatment under the law); citizenship and participation; administrative code; publicity and social rights". "Kebebasan Dasar (kebebasan berbicara dan berekspresi, kebebasan bergerak, kebebasan berserikat, hak atas perlakuan yang sama di bawah hukum), kewarganegaraan dan partisipasi, kode administrasi, publisitas dan hak sosial."

Dalam hubungannya dengan demokrasi, partisipasi politik berpengaruh terhadap legitimasi masyarakat terhadap jalannya suatu pemerintahan. Dalam suatu Pemilu misalnya partisipasi politik berpengaruh terhadap legitimasi masyarakat kepada pasangan calon yang terpilih. Setiap masyarakat memiliki preferensi dan kepentingan masing-masing untuk menentukan pilihan mereka dalam pemilu. Bisa dikatakan bahwa masa depan pejabat publik yang terpilih dalam suatu Pemilu tergantung pada preferensi masyarakat sebagai pemilih. Tidak hanya itu, partisipasi politik masyarakat dalam Pemilu dapat dipandang sebagai kontrol masyarakat terhadap suatu pemerintahan. Kontrol yang diberikan beragam tergantung dengan tingkat partisipasi politik masing-masing. Selain sebagai inti dari demokrasi, partisipasi politik juga berkaitan erat dengan pemenuhan hak-hak politik warga negara.
Partisipasi politik merupakan aspek penting dalam sebuah tatanan negara demokrasi, sekaligus merupakan ciri khas adanya modernisasi politik. Secara umum dalam masyarakat tradisional yang sifat kepemimpinan politiknya lebih ditentukan oleh segolongan elit penguasa, keterlibatan warga negara dalam ikut serta memengaruhi pengambilan keputusan, dan memengaruhi kehidupan bangsa relatif sangat kecil. Warga negara yang hanya terdiri dari masyarakat sederhana cenderung kurang diperhitungkan dalam proses-proses politik. ${ }^{2}$

Sebagai salah satu bagian dari hak warga, maka hak asasi manusia merupakan hak dasar yang di miliki oleh setiap manusia dan merupakan anugerah dari Tuhan Yang Maha Esa. Negara Republik Indonesia mengakui dan menjunjung tinggi hak asasi manusia dalam kegiatan politik khususnya dalam hal menentukan arah kebijakan lewat pemilu 2019 melalui hak suara yang di milikinya. Dalam Peraturan negara kita menyatakan bahwa seseorang yang berumur 17 tahun sudah memiliki KTP maka dia berhak mempunyai hak suara, tanpa terkecuali termasuk juga secara khusus kaum disabilitas.

\footnotetext{
${ }^{2}$ Sudijono Sastroatmodjo, Perilaku Politik. Semarang: Ikip Semarang Press, 2015.
} 
Terkait hal tersebut diatas maka negara wajib memberikan fasilitas kepada semua warga negara di Indonesia khususnya kaum disabilitas. Ini menjadi perwujudan negara yang demokrasi berkeadilan sosial menurut UUD 1945. Namun muncul persoalan kekinian bahwa dalam asas pemilu mengharuskan pemilu itu adalah jujur, adil, langsung, umum, bebas, rahasia. Jika hal itu kita kaitkan dengan kondisi kaum disabitas tadi, terutama disabilitas mental atau ada disebut juga dengan istilah orang dengan gangguan jiwa (ODGJ) ikut memilih, maka persoalan pemenuhan akan asas pemilu diatas akan berbenturan.

Namun pada dasarnya kita menginginkan partisipasi memilih tidak hanya dilihat pada angka secara kuantitatif, tapi juga bisa dilihat keterlibatan masyarakat dalam pemilihan umum secara kualitatif. Pada Pemilu sebelumnya jika di nilai partisipasi itu diluar aktivitas memilih sangat terbatas, namun seperti nya sekarang pada tahapan menjelang Pilpres 2019, keterlibatan publik dirasa lebih intents dan tinggi untuk mengawal proses pemilu. Misalnya saja kita bisa nilai bahwa antusiasme masyarakat tersebut dilihat dari partisipasi mengawal pemutakhiran daftar pemilih, tingginya pelaporan pelanggaran, dan mengawal proses tahapan pemilu melalui sosial media atau data digital KPU. Kesukarelaan warga negara untuk terlibat dalam proses ini mengalami peningkatan dengan relawan yang sifatnya tidak berafiliasi dengan kekuatan politik manapun, maupun yang berafiliasi.

Sebagaimana diketahui, angka partisipasi memilih itu dihitung dari total pengguna hak pilih dibagi pemilih yang terdaftar. Partisipasi memilih di Pilpres 2014 sebesar 69,58 persen. Partisipasi memilih ini berbanding lurus dengan angka golongan putih (golput). Sehingga bisa disebut angka golput pada Pilpres 2014 sebesar 30,42 persen meningkat dari Pilpres 2009 dan Pileg 2014.

Tabel 1.1

\section{Peningkatan Partisipasi Pemilih PILPRES}

\begin{tabular}{|c|c|}
\hline Tahun & Tingkat Partisipasi (\%) \\
\hline Pemilu Tahun 2004 & $84,1 \%$ \\
\hline Pemilu Tahun 2009 & $71,1 \%$ \\
\hline Pemilu Tahun 2014 & $69,6 \%$ \\
\hline
\end{tabular}

Sumber : KPU RI 2018

Seperti yang dikatakan Abdul

Aziz Saleh dalam Damsar (2015) disebutkan bahwa kehidupan pertumbuhan partisipasi memerlukan tata nilai yang operasional (dimanifestasikan dalam bentuk perilaku yang nyata), yang menerima dan menghargai persamaan, keterbukaan, perbedaan pendapat dan 
berpikir mempertanyakan (critical

thinking). Dan partisipasi dalam politik adalah salah satunya seperti menurut Herbert McClosky memberikan batasan partisipasi politik sebagai kegiatankegiatan sukarela dari warga masyarakat melalui mana mereka mengambil bagian dalam proses pemilihan penguasa dan secara langsung atau tidak langsung dalam proses pembentukan kebijakan umum. ${ }^{3}$ penyandang disabilitas. Untuk lebih jelasnya dapat dilihat pada tabel 1.2.

Tabel 1.2

REKAPITULASI DATA PENYANDANG DISABILITAS KABUPATEN HULU SUNGAI UTARA TAHUN 2016-2018

\begin{tabular}{|c|c|c|c|c|c|c|c|c|c|c|c|c|}
\hline \multirow[b]{2}{*}{ No } & \multirow[b]{2}{*}{ DATA PMKS } & \multicolumn{10}{|c|}{ KECAMATAN } & \multirow[b]{2}{*}{ JUMLAH } \\
\hline & & $\begin{array}{l}\text { Amt. } \\
\text { Tengah }\end{array}$ & $\begin{array}{c}\text { Amt. } \\
\text { Selatan }\end{array}$ & $\begin{array}{l}\text { Amt. } \\
\text { Utara }\end{array}$ & Banjang & $\begin{array}{c}\text { Haur } \\
\text { Gading }\end{array}$ & Babirik & $\begin{array}{c}\text { Danau } \\
\text { Panggang }\end{array}$ & Paminggir & $\begin{array}{l}\text { Sungai } \\
\text { Pandan }\end{array}$ & $\begin{array}{c}\text { Sungai } \\
\text { Tabukan }\end{array}$ & \\
\hline 1 & $\begin{array}{l}\text { Anak Dengan Kedisabilitas } \\
\text { (ADK) }\end{array}$ & 29 & 26 & 35 & 24 & 12 & 16 & 12 & 15 & 31 & 20 & 220 \\
\hline 2 & $\begin{array}{l}\text { Penyandang Disabilitas (Fisik } \\
\text { dan Mental) }\end{array}$ & 55 & 94 & 145 & 76 & 44 & 45 & 98 & 36 & 130 & 100 & 823 \\
\hline 3 & $\begin{array}{l}\text { Orang Dengan Gangguan } \\
\text { Jiwa (Pasungan }\end{array}$ & 4 & 9 & 4 & 3 & 3 & 5 & 4 & - & 2 & 6 & 40 \\
\hline & & 88 & 129 & 184 & 103 & 59 & 66 & 114 & 51 & 163 & 126 & 1083 \\
\hline
\end{tabular}

\section{Dalam Undang-Undang Pemilu}

disebutkan bahwa warga yang sudah berusia 17 tahun atau sudah menikah, bukan TNI dan Polri serta tak dicabut hak politiknya, wajib masuk dalam Daftar Pemilih Tetap (DPT). Dengan kata lain, memiliki hak suara. Termasuk penyandang disabilitas juga memiliki hak suara. Gangguan jiwa termasuk dalam

\footnotetext{
${ }^{3}$ Damsar, 2010, Pengantar Sosiologi Politik, Kencana Prenada Media Group ; Jakarta
} 
Karena itu pemilu merupakan wadah untuk menyampaikan ekspresi dan keinginan masyarakat dalam menentukan arah suatu negara yang diselenggarakan secara berkala, sehingga dalam Pemilu suara warga negara yang sudah memenuhi hak untuk memilih dihitung sama dimana setiap orang yang memenuhi persyaratan mendapatkan kesempatan untuk menyatakan pendapatnya secara langsung atau melalui perwakilan yang dipilih secara langsung. Karena hak ini tak tergantikan (non-derogable), partisipasi semua kalangan harus dilindungi tanpa kecuali. Tetapi pada satu sisi memunculkan permasalahan bagi penyandang disabilitas. Karena penyandang disabilitas merupakan kelompok yang membutuhkan sarana khusus agar mereka dapat memilih secara mandiri sehingga dapat memenuhi asas pemilu yaitu Langsung, Umum, Bebas dan Rahasia (LUBER). Sehingga hak politik penyandang disabilitas selama ini masih belum terpenuhi secara maksimal lewat penyediaan aksesibilitas dalam Pemilu bagi mereka. Terutama disabilitas mental atau ODGJ, di mana kelompok ini merupakan kelompok khusus yang butuh perlakuan khusus pula.
Sikap adil pada proses pemilu yakni kesamaan hak dan kesetaraan pada satu orang, satu suara, satu TPS, dan satu momentum hari pelaksanaan pemilu. Kondisi sedemikian ini akan memberikan pengaruh pada perubahan sikap masyarakat yang adil terhadap penyandang disabilitas diberbagai bidang kehidupan.

Padahal sudah jelas Payung hukum bagi disabilitas dalam Pemilu baik secara nasional maupun internasional, Undang-Undang (UU) Dasar 1945 setelah diamandemen Pasal $28 \mathrm{H}$ ayat 2: Setiap orang berhak mendapatkan kemudahan dan perlakuan khusus untuk memperoleh kesempatan dan manfaat yang sama guna mencapai persamaan dan keadilan. Dan Pasal 28 I ayat 2: Setiap orang berhak bebas dari perlakuan yang bersifat diskriminatif atas dasar apapun dan berhak mendapatkan perlindungan terhadap perlakuan yang bersifat diskriminatif.

Kewajiban untuk memberikan akses pemilu di tingkat internasional pertama kali ditetapkan melalui deklarasi Universal Hak-hak Azazi Manusia pada tahun 1948 dan selanjutnya mengalami proses perkembangan dari tahun ke tahun. Pada saat ini, Konvensi Hak-hak Budi Lesmana | Penerapan Aspek .... | 6 
Penyandang Disabilitas merupakan produk yang dengan jelas menyampaikan hak-hak asasi penyandang disabilitas.

Tetapi pada tingkat implementasi, ada masih benturan aspek hukum dan teknis yang sebetulnya menjadi kendala dan masalah, sehingga ketika kita membicarakan tingkat partisipasi politik masyarakat khususnya disabilitas ini akan menuai kontorversi dikalangan elite dan menjadi diskursus ditingkat masyarakat pada umumnya, namun di sisi lain KPU sebagai penyelenggara juga harus melaksanakan UU kepemiluan secara konsisten.

Atas dasar beberapa pemikiran dan uraian diatas serta alasan yang telah dikemukakan diatas maka terdapat permasalahan yang menarik untuk di teliti, maka kami selaku peneliti ingin melakukan penelitian dengan Judul :

Penerapan Aspek Rasionalitas Dalam Pemilu 2019 (Studi Terhadap Tingkat Partisipasi Politik ODGJ di Kabupaten Hulu Sungai Utara).

\section{B. Rumusan Masalah}

Berdasarkan latar belakang yang telah dijelaskan sebelumnya, maka penelitian ini dapat ditarik dua pertanyaan pokok, yaitu: Bagaimana menerapkan asas pemilu kepada Kelompok Disabilitas (ODGJ) dalam partisipasi politik dalam Pemilu Serentak tahun 2019?

\section{Tujuan Penelitian}

Adapun Penelitian mengenai partisipasi politik masyarakat bertujuan untuk mengetahui penerapan asas Pemilu kepada masyarakat dalam partisipasi politik dalam Pemilu Serentak Tahun 2019.

\section{BAB II}

\section{KERANGKA TEORITIK}

\section{Teori Partisipasi Politik}

Partisipasi politik memiliki pengertian yang beragam. Ada beberapa ahli yang mengungkapkan pendapatnya tentang partisipasi politik. Menurut Ramlan Surbakti yang dimaksud dengan partisipasi politik adalah keikutsertaan warga negara biasa dalam menentukan segala keputusan yang menyangkut atau memengaruhi hidupnya. ${ }^{4}$ Herbert McClosky seorang tokoh masalah partisipasi berpendapat bahwa partisipasi politik adalah kegiatankegiatan sukarela dari warga masyarakat melalui mana mereka mengambil bagian dalam proses

\footnotetext{
${ }^{4}$ Ramlan Surbakti, Memahami Ilmu Politik, Jakarta: PT. Gramedia Widisarana Indonesia, 2007
} 
pemilihan penguasa, dan secara langsung atau tidak langsung, dalam proses pembentukan kebijakan umum. ${ }^{5}$

Miriam Budiarjo secara umum mengartikan partisipasi politik sebagai kegiatan seseorang atau kelompok orang untuk ikut serta secara aktif dalam kehidupan politik yaitu dengan jalan memilih pimpinan negara secara langsung atau tidak langsung memengaruhi kebijakan pemerinah (public policy). ${ }^{6}$

Dari beberapa pendapat ahli tersebut maka yang dimaksud partisipasi politik adalah adanya kegiatan atau keikutsertaan warga negara dalam proses pemerintahan. Kemudian kegiatan tersebut diarahkan untuk memengaruhi jalannya pemerintahan. Sehingga dengan adanya partisipasi politik tersebut akan berpengaruh terhadap kehidupan mereka.

Menurut Ramlan Surbakti partisipasi politik terbagi menjadi dua yaitu partisipasi aktif dan pasrtisipasi pasif. Partisipasi aktif adalah mengajukan usul mengenai suatu kebijakan umum, mengajukan alternatif kebijakan umum yang berlainan dengan kebijakan yang

\footnotetext{
${ }^{5}$ Damsar, 2010, Pengantar Sosiologi Politik, Kencana Prenada Media Group ; Jakarta

${ }^{6}$ Miriam Budiardjo, Dasar-Dasar Ilmu Politik, Jakarta: PT Gramedia Pustaka Utama, 2008
}

dibuat pemerintah, mengajukan kritik dan perbaikan untuk meluruskan kebijakan, membayar pajak dan memilih pemimpin pemerintah. Sebaliknya, kegiatan yang termasuk dalam kategori partisipasi pasif berupa kegiatan-kegiatan yang menaati pemerintah, menerima, dan melaksanakan saja setiap keputusan pemerintah. $^{7}$

Sementara itu, Milbart dan Goel (Cholisin, 2007:152) membedakan partisipasi menjadi beberapa kategori. Pertama, apatis. Artinya, orang yang tidak berpartisipasi dan menarik diri dari proses politik. Kedua, spectator. Artinya, orang yang setidak-tidaknya pernah ikut memilih dalam pemilihan umum. Ketiga, gladiator. Artinya mereka yang secara aktif terlibat dalam proses politik, yakni komunikator, spesialis mengadakan kontak tatap muka, aktivis partai dan pekerja kampanye, dan aktivis masyarakat. ${ }^{8}$

\section{Teori Pilihan Rasional}

$$
\begin{array}{ccc}
\text { Teori } & \text { selanjutnya yang } \\
\text { digunakan oleh } & \text { peneliti adalah teori }
\end{array}
$$

\footnotetext{
${ }^{7}$ Ramlan Surbakti, op.,cit. hlm. 142

${ }^{8}$ Cholisin, dkk. 2007. Dasar-dasar Ilmu Politik, Yogyakarta; UNY Press
} 
pilihan rasional. Salah satu tokoh yang konsen terhadap teori pilihan rasional adalah James. S. Coleman. Teori pililan rasional Coleman tampak jelas dalam gagasan dasarnya bahwa tindakan perseorangan mengarah kepada sesuatu tujuan dan tujuan itu ditentukan oleh nilai atau pilihan. Coleman selajutnya menyinggung masalah adanya aktor yang memilih tindakan yang dapat memaksimalkan kegunaan atau memuaskan keinginan dan kebutuhan mereka. Ada dua unsur utama dalam teori Coleman. Yakni aktor dan sumber daya. Sumber daya adalah sesuatu yang menarik perhatian dan yang dapat dikontrol oleh aktor. Coleman mejelaskan interaksi antara aktor dan sumber daya secara rinci menuju ke tingkat sistem sosial. ${ }^{9}$

Varian mainstream dari pilihan rasional mengasumsikan bahwa individu mempunyai semua kapasitas rasional, waktu, dan keterikatan emosi yang penting untuk memilih arah tindakan baik, tak peduli betapa kompleksnya pilihan tersebut. Masalah paling sederhana secara konseptual dalam pembuatan keputusan parametrik dalam kepastian ketika setiap tindakan mempunyai hasil yang diketahui (sehingga tidak ada resiko

\footnotetext{
${ }^{9}$ James S. Coleman, 2013. Dasar-Dasar Teori Sosial ; Foundation of Social Theory, Bandung ; Nusa Media.
}

atau ketidakpastian) dan hubungan antara aksi dan akibat tak dipengaruhi oleh tindakan individu lain. Individu diasumsikan mampu menilai hasil, maupun aksi. Jadi untuk pasangan manapun dari alternatif a dan $b$, mereka bisa mengatakan apakah a lebih baik dari b, b lebih baik dari a, atau dua hasil itu tidak berbeda. Individu rasional akan memilih satu tindakan/hasil yang paling tinggi tingkat feasibilitasnya yang tersedia bagi mereka. ${ }^{10}$

Dalam pemilihan umum menurut Downs orang memilih calon atau partai apabila calon atau partai tersebut dipandang dapat membantu pemilih memenuhi kepentingan dasarnya yakni kehidupan ekonomi. Cukup dengan mempersepsikan keadaan ekonomi dirinya (egosentrik) dibawah sebuah pemerintahan (partai atau calon) tertantu sekarang ini dibanding sebelumnya (retrospektif), dan yang akan datang dibanding sekarang (retroospektif), dan yang akan datang dibanding sekarang (prospektif); dan evaluasi umum seorang pemilih atas keadaan ekonomi nasional (sosiotropik)

\footnotetext{
${ }^{10}$ George Ritzer \& Douglas J. Goodman. 2007. Teori Sosiologi Modern. Jakarta : Kencana.
} 
dibawah pemerintahan sekarang

dibanding tahun sebelumnya (retospektif), dan keadaan ekonomi nasional dibawah pemerintahan sekarang dibanding tahun-tahun yang akan datang (prospektif). ${ }^{11}$

Memahami permasalahan partisipasi politik dengan melihatnya dari pandangan teori pilihan rasional. Maka peneliti merasa perlu untuk menambahkan pula teori pilihan rasional Friedmen dan Hechter. Teori ini akan melengkapi teori sebelumnya dengan menjelaskan adanya pengaruh lembaga sosial dalam pilihan rasional. Friedmen dan Hechter dalam teori yang disebutnya model kerangka teori pilihan rasional memusatkan perhatian pada aktor. Aktor dipandang sebagai manusia yang mempunyai tujuan dan tindakanya tertuju pada upaya mencapai tujuan itu. ${ }^{12}$

Teori ini memperhatikan dua hal yang memengaruhi tindakan aktor. Pertama, keterbatasan sumber. Masing-masing aktor memiliki sumber yang berbeda maupun akses yang berbeda terhadap sumber tersebut. Dalam kelangkaan sumber daya terdapat gagasan mengenai biaya

\footnotetext{
${ }^{11}$ David Marsh \& Gerry Stoker. 2010. Teori dan Metode Dalam Ilmu Politik. Bandung: Nusa Media.$$
{ }^{12} \text { Ibid. }
$$

kesempatan. Dalam mencapai suatu tujuan, aktor harus memperhatikan biaya yang harus dikeluarkan untuk tindakan yang terpenting. Aktor dapat memilih tindakan untuk tidak mengejar tujuan paling bernilai jika sumber daya yang dimilikinya diperhitungkan tidak mencapai hal tersebut. Kedua, lembaga sosial. Hambatan kelembagaan menyediakan baik sanksi positif maupun sanksi negatif yang membantu mendorong aktor untuk melakukan tindakan tertentu dan menghindarkan tindakan yang lain.

\section{Partisipasi Politik dalam Pemilu}

\subsection{Pengaruh Lembaga Sosial}

\section{dalam Meningkatkan Partisipasi}

Politik

Tidak bisa dipungkiri bahwa lembaga sosial telah berperan besar dalam meningkatkan partisipasi politik masyarakat. Karena pada dasarnya seperti diungkap para ahli menjelaskan adanya kemampuan dari lembaga sosial untuk memberikan sanksi positif dan negatif kepada masyarakat sehingga memengaruhi masyarakat untuk menentukan ikut terlibat berpartisipasi ataukah tidak. Berdasarkan pengamatan peneliti, dalam konteks kepemiluan ada beberapa lembaga sosial yang turut 
berperan dalam meningkatkan partisipasi politik masyarakat tersebut antara lain adalah KPUD, Partai Politik, Media Massa, dan Ormas.

Pertama, Peran KPU. Sebagai penyelanggara Pemilu KPU memiliki peran utama meningkatkan partisipasi politik masyarakat khususnya dalam hal menggunakan hak pilihnya. Hal tersebut termuat dalam UU Nomor 7 Tahun 2017 Tentang Pemilihan Umum menyebutkan bahwa: "Salah satu tugas dan wewenang KPU Kabupaten/Kota adalah menyelenggarakan sosialisasi dan penyelenggaraan Pemilu dan atau yang berkaitan dengan tugas dan wewenang KPU Kabupaten/ Kota kepada masyarakat". ${ }^{13}$ KPUD meningkatkan partisipasi politik masyarakat melalui cara sosialisasi dan pendidikan politik masyarakat. Cara tersebut dilakukan melalui tiga tahapan yakni melalui komunikasi tatap muka, komunikasi melalui media, dan melalui mobilisasi sosial.

Kedua, peran Partai Politik. Partai politik dalam UU Nomor 2 tahun 2008 sebagaimana telah diubah menjadi UU Nomor 2 Tahun 2011 tentang Partai Politik pada Pasal 10 disebutkan: "tujuan khusus partai politik adalah meningkatkan partisipasi

\footnotetext{
${ }^{13}$ Undang_undang Nomor 7 tahun 2017 tentang Pemilu
}

politik anggota dan masyarakat dalam rangka penyelenggaraan kegiatan politik dan pemerintahan." Selanjutnya dalam pasal 11 dijelaskan: "Partai politik berfungsi sebagai sarana pendidikan politik bagi anggota dan masyarakat luas agar menjadi warga Negara Indonesia yang sadar akan hak dan kewajibannya dalam kehiudpan bermasyarakat, berbangsa dan bernegara." 14

Sosialisasi dan pendidikan politik oleh Partai Politik sedikitnya dilakukan dalam tiga hal, yakni: melalui sosialisasi para kader, pendidikan politik, dan melalui optimalisasi organisasi sayap partai.

Ketiga, Peran media massa. Tidak bisa dipungkiri bahwa dizaman digital dan era globalisasi seperti saat ini, media memiliki peran yang sangat besar dalam memberikan informasi kepada masyarakat. Interaksi media saat ini bukan hanya sekedar one away atau satu arah saja, tetapi sudah lebih interaktif dengan munculnya media social. Sehingga melalui media, terutamanya media social komunikasi antara pemerintah dengan masyarakat menjadi lebih mudah. Begitu juga ketika pelaksanaan pesta demokrasi Pemilu di Negara kita, media menjadi

${ }^{14}$ UU Nomor 2 tahun 2008 tentang Partai Politik 
saluran komunikasi yang sangat tepat untuk menyampaikan sosialisasi kepada masyarakat. Sebagai salah satu pilar demokrasi, Pers yang dalam hal ini adalah media ,massa harus dapat bersikap independen dan lembaga yang netral. Dengan begitu, dalam peningkatan partisipasi masyarakat media diharapkan mampu memberikan pembelajaran, informasi dan pendidikan serta motivasi kepada masyarakat untuk secar aktif berpartisipasi menggunakan hak pilihnya dalam Pemilu.

\section{Keempat, peran Civil Society.}

Kelompok masyarakat sipil, yang biasa tergabung dalam organisasi-organisasi kemasyarakatan, baik yang berlatar belakang Kepemudaan, Keagamaan, LSM maupun Perguruan Tinggi adalah merupakan kelompok penting yang dapat diberdayakan untuk membangun pemahaman dan kesadaran politik dimasyarakat. Organisasi masyarakat yang banyak bergerak dalam meningkatkan partisipasi politik masyarakat.

Pada dasarnya lembaga sosial yang sudah dijelaskan diatas bekerja dan berkegiatan dalam rangka mendorong kesadaran politik, pendidikan politik dan partisipasi masyarakat intinya memiliki cara yang sama yaitu melakukan sosialisasi, kampanye, penyebaran informasi dan memberikan pendidikan politik kepada masyarakat. Dengan pelibatan lebih banyak kelompok masyarakat atau lembaga sosial tersebut diharapkan masyarakat dari berbagai elemen terdorong untuk berpartisipasi.

\subsection{Rasionalitas Masyarakat dalam} Partisipasi Politik

Dalam pelaksanaannya dilapangan apa yang dilakukan oleh lembaga sosial dalam kegiatan sosialisasi dan pendidikan politik dan juga penyebaran informasi, dalam upaya meningkatkan partisipasi politik ternyata tidak serta mampu mendorong masyarakat untuk berpartispasi politik secara maksimal. Sehingga dalam hal ini peneliti melihat dari sisi lain mengenai pengaruh rasionalitas pemilih dalam partisipasi politik.

Pandangan ini sebenarnya tidak terlepas dari kedudukan manusia, dimana dari pemahaman manusia sebagai makhluk sosial, pada dasarnya manusia juga merupakan makhluk individu. Sebagai makhluk individu kecenderungan lebih memiliki tingkat rasionalitas dan emosional yang sangat tinggi. Sifat dasar dari makhluk rasional adalah lebih berpikiran praktis, normatif dan memperhitungkan kalkulasi untung 
rugi yang menjadi dasar setiap tindakan yang diambil atau diputuskannya. Hampir semua manusia akan berusaha mendapatkan barang yang dia ingikan dengan ongkos seminimal mungkin. Barang dalam hal ini memiliki pengertian yang sangat luas. Tidak hanya barang yang berwujud namun juga barang yang tidak berwujud seperti misalnya sebuah kebijakan atau perjanjian. Sedangkan ongkos dalam hal ini tidak selalu berhubungan dengan uang, namun juga termasuk waktu dan tenaga.

\section{Hubungannya}

ketika

rasionalitas ini dikaitkan dengan Pemilu, bahwasanya pikiran rasionalnyat akan muncul ketika mereka berpikir keuntungan apa yang akan mereka dapatkan ketika mereka terlibat dalam Pemilu dalam hal ini hak suara yang akan digunakan untuk memilih. Yang paling vulgar adalah ketika masyaPadahal disisi lain mereka sudah jelas mengelrakat pemilih menilai bahwa mereka akan memilih wakil atau pimpinannya, dan ketika mereka terpilih mereka akan mendapatkan penghasilan, kedudukan dan jabatan serta fasilitas mewah lainnya, sementara mereka sebagai pemilih mereka hanya dipakai pada saat diperlukan saja, maka mereka juga secara realistis menuntut kompensasi atas keterlibatan mereka.

Bahwa ada pengeluaran ongkos dalam Pemilu, tentu itu sesuatu yang wajar. Sehingga akhirnya seluruh ongkos dalam hal ini baik berupa tenaga dan waktu, bahkan materi mau tidak mau harus diperhitungkan. Masyarakat mulai berpikir apakah barang yang mereka dapatkan nantinya sebanding dengan ongkos yang mereka keluarkan. Hasil Pemilu merupakan sebuah barang ketika hasil tersebut telah berubah menjadi sebuah keputusan yang telah ditetapkan oleh KPU. Namun dalam hal ini apakah barang hasil Pemilu tersebut telah memberikan banyak keuntungan bagi masyarakat, itu soal lain bagi mereka.

Bagi masyarakat keuntungan hanya didapat oleh calon yang terpilih, sedangkan dampak langsung bagi mereka tidak mereka dapatkan. Sebagai contoh saja, dalam Pemilukada Kabupaten Hulu Sungai Utara Tahun 2017 menunjukkan fakta adanya peningkatan partisipasi politik sebesar 4\%. Peningkatan tersebut namun tidak lantas menjadi kabar bahagia bagi pemerintah khususnya atas upaya-upaya yang telah dilakukan dalam meningkatkan partisipasi politik. Karena pada kenyataanya saat ini sangat marak berkembang 
fenomena politik uang atau lebih dikenal dengan istilah money politic dalam Pemilukada. Bisa jadi meningkatnya partisipasi itu karena ada dukungan politik uang. Dana dalam perjalanan Pemerintahan nya, masyarakat tidak peduli lagi mereka merasa telah selesai urusannya ketika mendapat keuntungan sesaat ketika menjelang pemilihan.

Praktik money politic dalam Pemilu dapat dilihat dari pandangan teori pilihan rasional. Salah satu tokoh teori pilihan rasional yang terkenal adalah James S. Coleman. Coleman mengangap bahwa setiap tindakan yang dilakukan oleh seseorang dipengaruhi oleh tujuan dan nilai yang diinginkan oleh mereka. Selanjutnya menurut Coleman dalam teori pilihan rasional ada dua unsur yang terlibat yakni aktor dan sumber daya. Uang menjadi salah satu motivasi bagi seseroang untuk berpartisiapsi dalam politik. Dalam Pemilu sendiri yang dinamakan aktor adalah masyarakat dan para calon. Sedangkan sumber daya yang dimaksud adalah uang dan jabatan politik.

Coleman menjelaskan adanya interaksi antara aktor dan sumber daya. Masing-masing aktor dapat mengendalikan sumber daya. Baik masyarakat maupun para calon atau berafiliasi dengan calon yang memiliki kekuasaan dapat mengendalikan jabatan politik. Masyarakat memiliki hak untuk menentukan siapa calon yang akan terpilih diinginkan. Namun para elit dan calon yang memiliki kekuasaan, juga memiliki kemampuan untuk memengaruhi pilihan masyarakat. Disinilah kemudian kedua aktor tersebut saling memengaruhi dan membutuhkan untuk mencapai tujuan masing-masing.

Sehingga praktik politik uangpun tidak dapat terhindarkan. Hak pilih menjadi sesuatu yang bisa ditukar dengan rupiah. Dengan adanya transaksi tersebut maka kedua aktor ini akan sama-sama mendapatkan sumber daya yang mereka inginkan. Dimana pemilih dalam hal ini akan mendapatkan uang sedangkan calon akan mendapatkan suara untuk mencapai jabatan politik yakni berupa kemenangan dalam Pemilu.

Antoni Downs memberikan penjelasan mengenai adanya keterkaitan antara pemilihan umum dengan teori pilihan rasional. Kehidupan politik saat ini tidak hanya murni dipengaruhi oleh kepentingan politik. Namun sudah lebih banyak dipengaruhi oleh kepentingan ekonomi didalamnya. Begitu juga dengan Pemilu, banyak muncul pertimbangan- 
pertimbangan ekonomi yang dipikirkan

oleh masyarakat sebagai pemilih.

Seperti yang diungkapkan oleh Antony

Downs bahwa pilihan politik banyak ditentukan oleh evaluasi atau kondisi ekonomi, personal maupun kolektif. Masyarakat cenderung akan mempertimbangkan kehidupan ekonomi mereka pada masa pemerintahan sebelumnya, masa pemerintahan sekarang, dan masa pemeirntahan yang akan datang.

Dengan kondisi pilihan rasional ini juga, kita dapat menilai bagaimana penerapan partisipasi disabilitas mental atau ODGJ ini akan di lakukan. Tentu peluangnya terbesar yang bisa dimanfaatkan calon dalam Pemilu, agar kondisi yang mereka alami bisa didayagunakan dengan sumber kekuatan yang mereka punya dalam rangka untuk mendapatkan suara. Sehingga pada akhirnya keberadaan disabilitas dan ODGJ hanya menjadi objek.

\section{Disabilitas atau ODGJ}

\subsection{Latar Belakang ODGJ}

Mengutif

Dumilah

Ayuningtyas, Misnaniarti, Marisa Rayhani dalam Jurnal Ilmu Kesehatan Masyarakat, Maret 2018 tentang Analisis Situasi Kesehatan Mental Pada Masyarakat Di Indonesia Dan
Strategi

Penanggulangannya

disebutkan bahwa latar belakang gangguan jiwa adalah kondisi dimana proses fisiologis atau mental seseorang kurang berfungsi dengan baik sehingga mengganggu dalam fungsi sehari-hari. Gangguan ini juga sering disebut gangguan psikiatri atau gangguan mental dan dalam masyarakat umum kadang disebut sebagai gangguan saraf. Gangguan jiwa yang dimiliki oleh seseorang bisa memiliki bermacam-macam gejala, baik yang tampak jelas maupun yang hanya terdapat dalam pikirannya. Mulai dari perilaku menghindar dari lingkungan, tidak mau berhubungan atau berbicara dengan orang lain dan tidak mau makan hingga yang mengamuk dengan tanpa sebab yang jelas. Mulai dari diam saja hingga yang berbicara dengan tidak jelas. Ada pula yang dapat diajak bicara hingga yang tidak perhatian sama sekali dengan lingkungannya. Dampak gangguan jiwa antara lain gangguan dalam aktifitas sehari-hari, gangguan hubungan interpersonal dan gangguan fungsi dan peran sosial (Lestari, Choirriyah, \& Mathafi, 2014).

Orang-orang dengan gangguan jiwa (ODGJ) adalah istilah resmi bagi penyandang gangguan jiwa berdasarkan undang-undang kesehatan 
jiwa nomor 18 tahun 2014, ODGJ khususnya para penderita gangguan jiwa berat skizofrenia dan posikosis belum sepenuhnya mendapat perlakuan baik serta memenuhi hak asasi manusia.

Gangguan jiwa berat dapat menyebabkan turunnya produktivitas pasien dan akhirnya menimbulkan beban biaya besar yang dapat membebani keluarga, masyarakat, serta pemerintah. Lebih jauh lagi gangguan jiwa ini dapat berdampak pada penambahan beban negara dan penurunan produktivitas manusia untuk jangka panjang.

\subsection{Klasifikasi Gangguan Kesehatan}

\section{Mental}

Masih dari sumber yang sama, dikatakan gangguan mental menurut WHO, terdiri dari berbagai masalah, dengan berbagai gejala. Namun, mereka umumnya dicirikan oleh beberapa kombinasi abnormal pada pikiran, emosi, perilaku dan hubungan dengan orang lain. Contohnya adalah skizofrenia, depresi, cacat intelektual dan gangguan karena penyalahgunaan narkoba, gangguan afektif bipolar, demensia, cacat intelektual dan gangguan perkembangan termasuk autisme. Pada konteks kesehatan jiwa, dikenal dua istilah untuk individu yang mengalami gangguan jiwa. Pertama, Orang dengan Masalah Kejiwaan (ODMK) merupakan orang yang memiliki masalah fisik, mental, sosial, pertumbuhan dan perkembangan, dan/atau kualitas hidup sehingga memiliki risiko mengalami gangguan jiwa. Kedua, Orang dengan Gangguan Jiwa (ODGJ) adalah orang yang mengalami gangguan dalam pikiran, perilaku, dan perasaan yang termanifestasi dalam bentuk sekumpulan gejala dan/ atau perubahan perilaku yang bermakna, serta dapat menimbulkan penderitaan dan hambatan dalam menjalankan fungsi orang sebagai manusia.

Adapun kategori gangguan jiwa yang dinilai dalam data Riset Kesehatan Dasar (Riskedas) 2013 diketahui terdiri dari gangguan mental emosional (depresi dan ecemasan), dan gangguan jiwa berat (psikosis). Bentuk gangguan jiwa lainnya yaitu postpartum depression dan bunuh diri (suicide). Gangguan mental emosional atau distress psikologik merupakan keadaan yang mengindikasikan seseorang sedang mengalami perubahan psikologis. Gangguan ini berisiko menjadi lebih serius apabila tidak berhasil ditanggulangi. 


\subsection{Pengakuan Hak ODGJ}

Menurut Menteri Kesehatan RI, dr. Nafsiah Mboi, Sp.A, MPH, dalam artikel yang diambil dari dengan Judul ; STOP STIGMA DAN DISKRIMINASI TERHADAP ORANG DENGAN GANGGUAN JIWA (ODGJ) DIPUBLIKASIKAN PADA : JUMAT, 10 OKTOBER 2014, beliau merasa prihatin saat mendengar berbagai stigmatisasi dan diskriminasi yang masih sering dialami oleh anggota masyarakat yang dinilai berbeda dengan masyarakat pada umumnya, termasuk orang dengan gangguan jiwa (ODGJ), antara lain dikeluarkan dari sekolah, diberhentikan dari pekerjaan, diceraikan oleh pasangan, hingga ditelantarkan oleh keluarga, bahkan dipasung, serta dirampas harta bendanya. Untuk itu, Menkes mengajak seluruh jajaran kesehatan untuk segera dapat melaksanakan Empat Seruan Nasional Stop Stigma dan Diskriminasi terhadap ODGJ, yaitu: 1) Tidak melakukan stigmatisasi dan diskriminasi kepada siapapun juga dalam pelayanan kesehatan; 2) Tidak melakukan penolakan atau menunjukkan keengganan untuk memberikan pelayanan kesehatan kepada ODGJ; 3) Senantiasa memberikan akses masyarakat pada pelayanan kesehatan, baik akses pemeriksaan, pengobatan, rehabilitasi maupun reintegrasi ke masyarakat pasca perawatan di rumah sakit jiwa atau di panti sosial; serta 4) Melakukan berbagai upaya promotif dan preventif untuk mencegah terjadinya masalah kejiwaan, mencegah timbulnya dan/atau kambuhnya gangguan jiwa, meminimalisasi faktor risiko masalah kesehatan jiwa, serta mencegah timbulnya dampak psikososial.

Disamping itu, upaya lain yang tidak kalah pentingnya adalah Pemberdayaan ODGJ, yang bertujuan agar dapat hidup mandiri, produktif, dan percaya diri di tengah masyarakat, bebas dari stigma, diskriminasi atau rasa takut, malu serta ragu-ragu. Upaya ini sangat ditentukan oleh kepedulian keluarga dan masyarakat di sekitarnya, kata Menkes.

Komitmen dalam pemberdayaan ODGJ diperkuat dengan diterbitkannya Undang-undang Nomor 18 tahun 2014 tentang Kesehatan Jiwa yang baru saja disahkan pada 8 Agustus 2014 lalu. Undang-Undang Nomor 18 tahun 2014 tentang Kesehatan Jiwa ditujukan untuk menjamin setiap orang agar dapat mencapai kualitas hidup yang baik, serta memberikan pelayanan kesehatan 
secara terintegrasi, komprehensif, dan berkesinambungan melalui upaya promotif, preventif, kuratif, dan rehabilitatif.

Secara garis besar, Undangundang tersebut mengamanatkan tentang: 1) Perlunya peran serta masyarakat dalam melindungi dan memberdayakan ODGJ dalam bentuk bantuan berupa: tenaga, dana, fasilitas, pengobatan bagi ODGJ; 2) Perlindungan terhadap tindakan kekerasan, menciptakan lingkungan yang kondusif, memberikan pelatihan keterampilan; dan 3) Mengawasi penyelenggaran pelayanan di fasilitas yang melayani ODGJ.

\section{BAB III \\ METODE PENELITIAN}

\section{A. Pendekatan dan Jenis Penelitian}

Pada penelitian yang akan dilakukan ini, pendekatan kualitatif. Cara ini ditempuh oleh karena adanya kecenderungan "sifat permasalahan yang belum jelas, bersifat holistik, kompleks, dinamis serta penuh makna" sebagaimana diungkapkan Wahyu (2007:50). Sarman (2002:30) menambahkan, "Metode penelitian kualitatif bermaksud untuk meramu secara ilmiah pelbagai informasi yang dibangun, dikembangkan dan disampaikan oleh manusia atau komunitas tertentu yang notabene merupakan obyek dan sekaligus subyek dalam penelitian sosial".

Adapun jenis penelitian yang digunakan bersifat deskriptif sebagaimana dimungkinkan dalam pendekatan kualitatif. Sarman (2003:18) menyatakan bahwa "penelitian deskriptif kualitatif menggunakan metode-metode kualitatif untuk mengeksplorasi makna-makna, beragam variasi, dan pemahaman perseptual yang menyebabkan munculnya fenomena diteliti”.

\section{B. Lokasi Penelitian}

Penelitian dilakukan di Kabupaten Hulu Sungai Utara meliputi yang meliputi 10 Kecamatan dimana hal itu dimaksudkan karena preferensi penelitian berdasarakan pada data penduduk, data pemilih dan data disabilitas atau ODGJ yang ada di Kabupaten Hulu Sungai Utara.

\section{Sumber data}

Berangkat dari permasalahan yang hendak dibahas, maka untuk menentukan subjek penelitian dipergunakan cara purposive sampling. Sarman (2002:79) 
menyebutkan, kalau purposive sampling yang dipilih, maka peneliti 'dengan sengaja' harus memilih sampel observasinya yang dipercaya akan dapat memberikan pemahaman komprehensif tentang gejala yang akan diteliti.

\section{Teknik Pengumpulan Data}

Data-data yang dikumpulkan dalam penelitian ini akan berupa data primer dan data sekunder yang diperoleh melalui teknik triangulasi dengan menggabungkan observasi, wawancara terstruktur, dan juga dokumentasi. Azwar (2003:91) mengungkapkan, data primer merupakan data yang diperoleh secara langsung dari subjek penelitian dengan mengenakan alat pengukuran atau alat pengumpulan data langsung pada subjek sebagai sumber informasi yang dicari. Sedangkan data sekunder adalah data yang diperoleh lewat pihak lain atau diperoleh oleh peneliti tidak secara langsung dari subjek penelitian.

\section{E. Teknik Analisa Data}

Miles dan Huberman (Wahyu dkk,2007:60) mengemukakan bahwa aktivitas dalam analisis data kualitatif dilakukan secara interaktif dan berlangsung secara terus-menerus sampai tuntas sehingga datanya sudah jenuh. Aktivitas-aktivitas sebagaimana dimaksudkan tersebut adalah :

1. Data Reduction (Reduksi Data) Mengingat dalam Miles dan Huberman (Wahyu dkk,2007:60), 'mereduksi data berarti merangkum, memilih hal-hal yang pokok, memfokuskan pada hal-hal yang penting, dicari tema dan polanya. Dalam mereduksi data, setiap peneliti akan dipandu oleh tujuan yang akan dicapai'.

2. Data Display (Penyajian Data) Data-data yang diperoleh di lapangan berkaitan dengan focus penelitian, baik data primer atau data sekunder selanjutnya "diorganisasikan terutama dalam bentuk teks naratif" sebagaimana dikatakan Miles dan Huberman (Wahyu dkk, 2007:61). Melalui penyajian data maka data terorganisasikan, tersusun dalam pola hubungan sehingga akan semakin mudah dipahami. Dalam melakukan display data, selain dengan teks yang naratif, juga dapat berupa grafik, matrik, network (jejaring kerja), dan chart.

3. Conclusion Drawing/Verification Usai tahap penyajian data dilakukan, langkah berikutnya dalam penelitian ini adalah 
penarikan kesimpulan dan verifikasi terhadap data-data yang sudah terorganisir tersebut. Hal ini dikarenakan boleh jadi data-data yang telah diperoleh, belumlah mencukupi untuk menjelaskan secara lengkap berkenaan dengan kondisi masalah yang diteliti. Melalui penarikan kesimpulan dan verifikasi dapat diidentifikasi kekosongan data yang belum terisi ketika dilakukan pengumpulan data sebelumnya.

Penarikan kesimpulan dan verifikasi di sini dimungkinkan sebab seperti diungkapkan Miles dan Huberman (Wahyu dkk,2007:62), 'Kesimpulan awal yang dikemukakan masih bersifat sementara dan akan berubah bila ditemukan bukti-bukti kuat yang mendukung pada tahap pengumpulan data berikutnya'.

\section{PEMBAHASAN}

\section{DEMOGRAFI}

\section{Wilayah}

Secara geografis, Kabupaten Hulu Sungai Utara terletak antara koordinat
$2^{0} 17$ sampai $2^{0} 33$ Lintang Selatan dan antara $114^{0} 52$ sampai $115^{0} 24$ Bujur Timur. Kabupaten yang beribukota di Amuntai ini mempunyai luas wilayah $915,5 \mathrm{~km}^{2}$ atau hanya 2,38 persen dibandingkan dengan luas wilayah Provinsi Kalimantan Selatan.

Kabupaten yang terletak di bagian utara Provinsi Kalimantan Selatan ini pada bagian utara berbatasan dengan Kabupaten Barito Selatan (Provinsi Kalimantan Tengah) dan Kabupaten Tabalong, sebelah selatan dibatasi oleh Kabupaten Hulu Sungai Selatan dan Kabupaten Hulu Sungai Tengah, sebelah timur oleh Kabupaten Balangan, dan sebelah barat oleh Kabupaten Barito Selatan (Provinsi Kalimantan Tengah).

Secara administratif, sejak tahun 2008 Kabupaten Hulu Sungai Utara terbagi menjadi 10 (sepuluh) Kecamatan dengan 219 desa. Kecamatan Paminggir merupakan kecamatan terluas yang mencakup 23,81 persen dari luas wilayah Kabupaten Hulu Sungai Utara. Sedangkan Kecamatan yang memiliki luas terkecil adalah Kecamatan Sungai Tabukan yang luasnya $17,50 \mathrm{~km}^{2}$ atau hanya 1,91 persen dari luas wilayah Kabupaten Hulu Sungai Utara. Secara morfologi, seluruh kecamatan di Kabupaten Hulu Sungai Utara berada pada kemiringan 0-2 \% dan di kelas ketinggian 0-7 $\mathrm{m}$ dari permukaan air laut. 
Jika diamati dari segi pemanfaatan lahan, maka sebagian besar wilayah Hulu Sungai Utara masih berupa hutan rawa yaitu seluas $29.711 \mathrm{Ha}(32,52$ persen $)$ dan persawahan $25.492 \mathrm{Ha}(27,91$ persen $)$. Sedangkan yang dimanfaatkan sebagai pemukiman tempat tinggal baru seluas 4.285 Ha (4,69 persen). Selebihnya, 31.862 Ha (34,88 persen) atau lebih dari sepertiga luas wilayah Hulu Sungai Utara berupa hamparan rumput rawa dan danau. Pemerintah perlu memikirkan perencanaan ke depan tentang pengembangan danau dan lahan rawa agar bisa lebih dimanfaatkan secara ekonomis maupun secara sosial.

\section{Kependudukan}

Jumlah penduduk Kabupaten Hulu Sungai Utara berdasarkan data semester 2 tahun 2018 adalah 228.006 jiwa/orang yang terdiri dari 113.920 jiwa laki-laki dan 114.086 jiwa perempuan. Yang tersebar di 219 kelurahan/ desa. Kabupaten dengan luas wilayah $915,50 \mathrm{~km}^{2}$ ini memiliki kepadatan penduduk (population density) 236 jiwa per $\mathrm{km}^{2}$ dan rata-rata setiap keluarga terdiri dari 4 orang.

Tabel 4.I. Luas Wilayah, Jumlah Desa/ Kelurahan, Dan Penduduk Tiap Kecamatan Tahun 2018

\begin{tabular}{|c|c|c|c|c|c|}
\hline \multirow{2}{*}{ Kecamatan } & \multirow{2}{*}{$\begin{array}{l}\text { Luas } \\
\text { Area } \\
\left(\mathrm{Km}^{2}\right)\end{array}$} & \multicolumn{3}{|c|}{ Jumlah / Total } & \multirow[b]{2}{*}{ Total } \\
\hline & & Desa/Kel. & Laki-Laki & Perempuan & \\
\hline (1) & (2) & (3) & (4) & $(5)$ & \\
\hline 1. Danau Panggang & 133,50 & 16 & 10.444 & 10.189 & 20.633 \\
\hline 2. Paminggir & 217,50 & 7 & 4.018 & 3.893 & 7.911 \\
\hline 3. Babirik & 74,00 & 23 & 9.954 & 9.895 & 19.849 \\
\hline 4. Sungai Pandan & 61,50 & 33 & 14.013 & 14.241 & 28.254 \\
\hline 5. Sungai Tabukan & 17,50 & 17 & 7.600 & 7.584 & 15.184 \\
\hline 6. Amuntai Selatan & 174,00 & 30 & 14.976 & 14.827 & 29.803 \\
\hline 7. Amuntai Tengah & 80,50 & 29 & 25.401 & 25.718 & 51.119 \\
\hline 8. Banjang & 89,50 & 20 & 9.342 & 9.017 & 18.359 \\
\hline 9. Amuntai Utara & 37,00 & 26 & 10.294 & 10.544 & 20.838 \\
\hline 10. Haur Gading & 28,50 & 18 & 7.878 & 8.178 & 16.056 \\
\hline $\begin{array}{c}\text { Jumlah / Total } \\
2018\end{array}$ & $\mathbf{9 1 5 , 5 0}$ & 219 & 113.920 & 114.086 & 228.006 \\
\hline
\end{tabular}

Tabel 4.2. Data Pemilih Pemilu 2019 Kabupaten Hulu Sungai Utara 


\begin{tabular}{|c|c|c|c|c|c|c|}
\hline \multirow{2}{*}{ No } & \multirow{2}{*}{ Kecamatan } & \multirow{2}{*}{$\begin{array}{c}\text { Jumlah } \\
\text { Desa } \\
\end{array}$} & \multirow{2}{*}{$\begin{array}{c}\text { Jumlah } \\
\text { TPS } \\
\end{array}$} & \multicolumn{3}{|c|}{ Jumlah Pemilih } \\
\hline & & & & Laki-Laki & Perempuan & $\mathrm{L}+\mathrm{P}$ \\
\hline 1. & Danau Panggang & 16 & 66 & 7.284 & 7.428 & 14.712 \\
\hline 2. & Babirik & 23 & 69 & 6.816 & 7.008 & 13.824 \\
\hline 3. & Sungai Pandan & 33 & 95 & 9.724 & 10.251 & 19.975 \\
\hline 4. & Amuntai Selatan & 30 & 96 & 10.302 & 10.590 & 20.892 \\
\hline 5. & Amuntai Tengah & 29 & 163 & 17.288 & 18.110 & 35.398 \\
\hline 6. & Amuntai Utara & 26 & 73 & 7.277 & 7.673 & 14.950 \\
\hline 7. & Banjang & 20 & 57 & 6.430 & 6.341 & 12.771 \\
\hline 8. & Haur Gading & 18 & 51 & 5.472 & 5.968 & 11.440 \\
\hline 9. & Paminggir & 7 & 27 & 2.932 & 2.831 & 5.763 \\
\hline 10. & Sungai Tabukan & 17 & 50 & 5.379 & 5.543 & 10.922 \\
\hline & TOTAL & 219 & 747 & 78.904 & 81.743 & 160.647 \\
\hline
\end{tabular}

Sumber : KPU Kab. Hulu Sungai Utara 2019

Tabel 4.3. Data Pemilih Difabel Pemilu 2019 Kabupaten Hulu Sungai Utara

\begin{tabular}{|c|c|c|c|c|c|c|c|c|c|}
\hline \multirow[b]{2}{*}{ No } & \multirow[b]{2}{*}{ Kecamatan } & \multirow[b]{2}{*}{$\begin{array}{c}\text { Jumlah } \\
\text { Desa }\end{array}$} & \multirow[b]{2}{*}{$\begin{array}{c}\text { Jumlah } \\
\text { TPS }\end{array}$} & \multicolumn{6}{|c|}{ Kategori Difabel } \\
\hline & & & & $\begin{array}{c}\text { Tuna } \\
\text { Daksa }\end{array}$ & $\begin{array}{l}\text { Tuna } \\
\text { Netra }\end{array}$ & $\begin{array}{l}\text { Tuna Rungu } \\
\text { /Wicara }\end{array}$ & $\begin{array}{c}\text { Tuna } \\
\text { Grahita }\end{array}$ & $\begin{array}{c}\text { Disabilitas } \\
\text { lainnya }\end{array}$ & Jumlah \\
\hline 1. & Danau Panggang & 12 & 21 & 8 & 4 & 11 & 6 & 3 & 32 \\
\hline 2. & Babirik & 21 & 38 & 10 & 0 & 16 & 14 & 23 & 63 \\
\hline 3. & Sungai Pandan & 30 & 51 & 25 & 11 & 16 & 18 & 7 & 77 \\
\hline 4. & Amuntai Selatan & 20 & 43 & 16 & 7 & 18 & 19 & 11 & 71 \\
\hline 5. & Amuntai Tengah & 22 & 61 & 13 & 13 & 23 & 37 & 14 & 100 \\
\hline 6. & Amuntai Utara & 22 & 39 & 12 & 5 & 10 & 36 & 21 & 84 \\
\hline 7. & Banjang & 16 & 28 & 17 & 4 & 10 & 15 & 4 & 50 \\
\hline 8. & Haur Gading & 15 & 27 & 15 & 9 & 11 & 9 & 10 & 54 \\
\hline 9. & Paminggir & 3 & 5 & 5 & 1 & 0 & 2 & 3 & 11 \\
\hline 10. & Sungai Tabukan & 16 & 38 & 20 & 12 & 19 & 18 & 15 & 84 \\
\hline \multirow{2}{*}{\multicolumn{2}{|c|}{ TOTAL }} & \multirow[b]{2}{*}{177} & \multirow[b]{2}{*}{351} & 141 & 66 & 134 & 174 & 111 & 626 \\
\hline & & & & $\begin{array}{l}L=75 \\
P=66\end{array}$ & $\begin{array}{l}L=28 \\
P=38\end{array}$ & $\begin{array}{l}L=66 \\
P=68\end{array}$ & $\begin{array}{l}\mathbf{L}=\mathbf{9 7} \\
\mathbf{P}=77\end{array}$ & $\begin{array}{l}\mathbf{L}=\mathbf{5 1} \\
\mathbf{P}=\mathbf{6 0}\end{array}$ & $\begin{array}{l}L=318 \\
P=308\end{array}$ \\
\hline
\end{tabular}

Sumber : Di olah, KPU Kab. Hulu Sungai Utara 2019

Tabel 4.4. Sebaran Data Pemilih Difabel Khusus Tuna Grahita (ODGJ) Pemilu 2019

Kabupaten Hulu Sungai Utara 


\begin{tabular}{|r|l|c|c|c|}
\hline \multirow{2}{*}{ No } & \multirow{2}{*}{ Kecamatan } & \multicolumn{3}{|c|}{ Pemilih Tuna Grahita (ODGJ) } \\
\cline { 3 - 5 } & & Laki-Laki & Perempuan & Jumlah \\
\hline 1. & Danau Panggang & 3 & 3 & 6 \\
\hline 2. & Babirik & 9 & 5 & 14 \\
\hline 3. & Sungai Pandan & 6 & 12 & 18 \\
\hline 4. & Amuntai Selatan & 10 & 9 & 19 \\
\hline 5. & Amuntai Tengah & 20 & 17 & 37 \\
\hline 6. & Amuntai Utara & 16 & 20 & 36 \\
\hline 7. & Banjang & 12 & 3 & 15 \\
\hline 8. & Haur Gading & 7 & 2 & 9 \\
\hline 9. & Paminggir & 2 & 0 & 2 \\
\hline 10. & Sungai Tabukan & 12 & 6 & 18 \\
\hline & TOTAL & $\mathbf{9 7}$ & $\mathbf{7 7}$ & $\mathbf{1 7 4}$ \\
\hline
\end{tabular}

Sumber : Di olah, KPU Kab. Hulu Sungai Utara 2019

\section{ASPEK HUKUM HAK MEMILIH DISABILITAS}

Dalam konteks hukum, kedudukan seluruh warga Negara adalah sama dan sederajat. Mengutip pernyataan salah satu anggota Komisioner Komnas HAM, Bapak H. Hairansyah, SH, MH saat diwawancara, mengatakan bahwa sesuai Pasal 12 DUHAM yang berbunyi "Hak untuk memperoleh perlakuan yang menunjukan penghormatan terhadap harkat dan martabat manusia". Sudah jelas bahwa sebetulnya hak yang melekat pada diri manusia itu mutlak harus dihargai dengan penuh keadilan.

Salah satu perwujudan negara dalam kehidupan politik bangsa adalah menyelenggarakan pesta demokrasi yang dinamakan Pemilu setiap 5 tahun. Indonesia sendiri merupakan salah satu contoh negara demokrasi yang menerapkan Pemilu sebagai proses memilih pemimpin dengan melibatkan seluruh masyarakat yang memenuhi syarat sebagai pemilih. Fakta ini tentunya tidak luput dari pasal 1 UUD 1945 yang menyatakan bahwa Indonesia adalah negara demokrasi. Dan yang terbaru adalah telah terselenggarakannya Pemilu Serentak tahun 2019 yang menyelenggarakan Pemilihan Umum Legislatif dan sekaligus Pemilihan Presiden dan Wakil Presiden.

Dalam kedudukan hukum warga Negara, telah diatur bagaimana ketentuan dan tatacara bagi warga masyarakat yang memiliki hak suara agar adapat terlibat atau berpartisipasi dalam Pemilu. Ketentuan tersebut secara umum meliputi :

1. Terdaftar Sebagai Pemilih

Syarat wajib yang harus dimiliki oleh pemilih sebelum ikut serta dalam proses pemilu adalah datanya sudah terdaftar dalam 
daftar pemilih di setiap daerahnya. Akan tetapi, dalam proses sebelum pemilu biasanya terjadi kasus bahwa pemilih tidak terdaftar sebagai pemilih di daerah tersebut. Mengapa bisa demikian? Ada beberapa hal yang mempengaruhinya, diantaranya:

- Pemilih tersebut bukan asli warga di daerah tersebut,

- Pemilih merupakan orang yang baru saja pindah dari tempat tinggal lamanya, sehingga pemilih tersebut terdaftar di tempat tinggal lamanya.

- Pemilih yang melakukan kegiatan ekonomi atau usaha di luar daerah tempat tinggalnya dalam kurun waktu yang cukup lama tetapi tidak merubah alamat domisili

\section{WNI}

Syarat pemilih dalam pemilu di Indonesia yang wajib selanjutnya adalah berkebangsaan Indonesia atau WNI. Pemilih tidak boleh berkebangsaan ganda, karena nanti bisa saja menimbulkan polemik negeri. Jadi, apabila pemilih memiliki kewarganegaraan ganda, maka harus berganti menjadi kewarganegaraan Indonesia secara penuh. Adapun diantaranya adalah:
- Usianya sudah mencapai 18 tahun atau sudah menikah meskipun belum 18 tahun

- Memiliki tubuh yang sehat secara jasmani maupun rohani

- Ketika mengajukan permohonan menjadi WNI, setidaknya sudah tinggal di Indonesia minimal 5 tahun berturut-turut atau 10 tahun tetapi tidak berturut-turut

- Dapat berkomunikasi menggunakan bahasa Indonesia dan mengakui bahwa dasar negara Indonesia adalah Pancasila dan UUD 1945

- Tidak atau belum pernah terjerat kasus hukuman pidana dengan ancaman 1 tahun atau bahkan lebih

\section{Memiliki E-KTP}

Kewajiban yang telah diatur oleh Pemerintah adalah bagi setiap warga Negara harus memiliki identitas yang resmi dan itu dibuktikan dengan adanya Kartu Tanda Penduduk (KTP). Dalam perkembangannya pemerintah telah mengatur KTP sebagai bentuk single indentity warga yang telah diperbaharui ke dalam bentuk E-KTP. Oleh karenaya dalam ketentuan pelaksanaan pemilu 2019, setiap pemilih wajib sudah memiliki E-KTP sebagai syarat memilih. 


\section{Sehat Jasmani dan Rohani}

Persyaratan selanjutnya adalah sehat jasmani dan rohani. Sehat yang dimaksudkan disini adalah sehat dari segi akal pikirannya dan tidak mengalami gangguan kejiwaan. Mengapa persyaratan ini juga wajib? Karena apabila seorang pemilih kejiwaannya terganggu, mereka bisa saja dipengaruhi oleh para calon-calon yang akan dipilih dan bisa saja hak pilihnya disalahgunakan. Jadi, setidaknya bagi para pemilih harus memiliki tubuh yang sehat, baik secara jasmani maupun rohaninya agar tidak terjadi penyalahgunaan hak dan wewenang.

\section{Haknya Masih Terdaftar (Tidak di} Cabut)

Hal ini berhubungan dengan status seseorang yang sedang dalam perkara hukum. Di mana dalam putusan pengadilan tidak mencabut hak-hak sebagai warga Negara. Sehingga posisinya masih memiliki kedudukan hukum yang sama dalam politik untuk dipilih atau memilih dalam Pemilu.

Dalam ketentuan yang lebih khusus terkait syarat pemilih diatur dalam PKPU No.11 tahun 2109 tentang Perubahan Kedua atas Peraturan Komisi Pemilihan
Umum No.11 tahun 2018 tentang Penyususnan Daftar Pemilih di dalam Negeri Dalam Penyelenggaraan Pemilihan Umum, di mana dalam Pasal 4 (1) Untuk dapat menggunakan hak memilih, Warga Negara Indonesia harus terdaftar sebagai Pemilih kecuali yang ditentukan lain dalam Undang-Undang. Kemudian dalam ayat (2) Pemilih sebagaimana dimaksud pada ayat (1) harus memenuhi syarat: a. genap berumur 17 (tujuh belas) tahun atau lebih pada hari pemungutan suara, sudah kawin, atau sudah pernah kawin; b. tidak sedang terganggu jiwa/ingatannya; c. tidak sedang dicabut hak pilihnya berdasarkan putusan pengadilan yang telah mempunyai kekuatan hukum tetap; d. berdomisili di wilayah administratif Pemilih yang dibuktikan dengan KTP-el; e. dalam hal Pemilih belum memiliki KTP-el sebagaimana dimaksud dalam huruf $\mathrm{d}$, Pemilih dapat menggunakan Surat Keterangan perekaman KTP-el yang dikeluarkan oleh dinas kependudukan dan catatan sipil atau instansi lain yang sejenisnya yang memiliki kewenangan untuk itu; dan f. tidak sedang menjadi anggota Tentara Nasional Indonesia, atau Kepolisian Negara Republik Indonesia. Ayat (3) Pemilih yang sedang terganggu jiwa/ingatannya sebagaimana dimaksud pada ayat (2) huruf b, sehingga tidak memenuhi syarat sebagai Pemilih, harus dibuktikan dengan surat keterangan dokter. 
Membaca ketentuan diatas, sudah diatur jelas bagaimana syarat bagi warga Negara Indonesia yang meliki hak pilih untuk ikut terlibat dalam Pemilu. Tanpa kecuali termasuk juga Pemilih yang terganggu jiwanya tetap dapat ikut memilih dengan ketentuan memenuhi syarat yang harus dibuktikan dengan surat keterangan dokter. Secara legal hukum sudah jelas kedudukan pemilih, namun tinggal bagaimana secara teknis proses dan prosedur pelaksanaan dilapangan dapat mengakomodir seluruh kelompok termasuk disabilitas secara khusus disabilitas mental (Tuna Grahita) dapat menyalurkan hak suara nya secara lancar.

\section{Hak Kelompok Disabilitas Dalam Politik}

Mengutip penjelasan $r$ Kabid
Rehabilitasi Sosial Dinas
Kabupaten Hulu Sungai Utara, Ibu Hj.
Rahmi, S.Sos, M.AP, bahwa dalam data
instansi mereka, untuk kelompok
masyarakat berkebutuhan khusus ini
mereka kelompok kan dalam kategori
Disabilitas. Di mana kelompok ini dibagi
menjadi dua yaitu disabilitas fisik dan
disabilitas mental. Dalam kelompok
disabilitas inilah termasuk orang dengan
gangguan jiwa.

Penyandang disabilitas adalah orang yang memiliki keterbatasan fisik, mental, intelektual atau sensorik dalam jangka waktu lama yang dalam berinteraksi dengan lingkungan dan sikap masyarakatnya dapat menemui hambatan yang menyulitkan untuk berpartisipasi penuh dan efektif berdasarkan kesamaan hak (Undang-Undang Nomor 19 Tahun 2011 Tentang Pengesahan Hak-Hak Penyandang Disabilitas).

Pengertian, Jenis dan Hak Penyandang Disabilitas

Penyandang Disabilitas

Istilah disabilitas berasal dari bahasa inggris yaitu different ability yang artinya manusia memiliki kemampuan yang berbeda. Terdapat beberapa istilah penyebutan menunjuk pada penyandang disabilitas, Kementerian Sosial menyebut dengan istilah penyandang cacat, Kementerian Pendidikan Nasional menyebut dengan istilah berkebutuhan khusus dan Kementerian Kesehatan menyebut dengan istilah Penderita cacat.

Berikut ini beberapa pengertian penyandang disabilitas dari beberapa sumber : 
Menurut Resolusi PBB Nomor 61/106 tanggal 13 Desember 2006, penyandang disabilitas merupakan setiap orang yang tidak mampu menjamin oleh dirinya sendiri, seluruh atau sebagian, kebutuhan individual normal dan/atau kehidupan sosial, sebagai hasil dari kecacatan mereka, baik yang bersifat bawaan maupun tidak, dalam hal kemampuan fisik atau mentalnya.

Menurut Undang-undang Nomor 39 Tahun 1999 tentang Hak Asasi Manusia, penyandang cacat/disabilitas merupakan kelompok masyarakat rentan yang berhak memperoleh perlakuan dan perlindungan lebih berkenaan dengan kekhususannya.

Menurut Undang-undang Nomor 11 Tahun 2009 tentang Kesejahteraan Sosial, penyandang cacat/disabilitas digolongkan sebagai bagian dari masyarakat yang memiliki kehidupan yang tidak layak secara kemanusiaan dan memiliki kriteria masalah sosial.

Menurut Undang-Undang Nomor 4 Tahun 1997 tentang Penyandang Cacat, penyandang disabilitas adalah setiap orang yang mempunyai kelainan fisik dan/atau mental, yang dapat menganggu atau merupakan rintangan dan hamabatan baginya untuk melakukan secara selayaknya, yang terdiri dari, penyandang cacat fisik; penyandang cacat mental; penyandang cacat fisik dan mental.

Menurut Undang-Undang Nomor 8 Tahun 2016 tentang Penyandang Disabilitas, Penyandang disabilitas adalah setiap orang yang mengalami keterbatasan fisik, intelektual, mental, dan atau sensorik dalam jangka waktu lama yang dalam berinteraksi dengan lingkungan dapat mengalami hambatan dan kesulitan untuk berpartisipasi secara penuh dan efektif dengan warga Negara lainnya berdasarkan kesamaan hak.

\section{Jenis-jenis Penyandang Disabilitas}

Menurut Undang-Undang Nomor 4 Tahun 1997 tentang Penyandang Cacat, Penyandang Disabilitas dikategorikan menjadi tiga jenis, yaitu sebagai berikut :

a. Cacat Fisik

Cacat fisik adalah kecacatan yang mengakibatkan gangguan pada fungsi tubuh, antara lain gerak tubuh, penglihatan, pendengaran, dan kemampuan berbicara. Cacat fisik antara lain: cacat kaki, cacat punggung, cacat tangan, cacat jari, cacat leher, cacat netra, cacat rungu, cacat wicara, cacat raba (rasa), cacat pembawaan.

Cacat tubuh atau tuna daksa berasal dari kata tuna yang berarati rugi atau kurang, 
sedangkan daksa berarti tubuh. Jadi tuna daksa ditujukan bagi mereka yang memiliki anggota tubuh tidak sempurna.

\section{b. Cacat Mental}

Cacat mental adalah kelainan mental dan atau tingkah laku, baik cacat bawaan maupun akibat dari penyakit, antara lain: retardasi mental, gangguan psikiatrik fungsional, alkoholisme, gangguan mental organik dan epilepsi. Seringkali disebut juga Tuna Grahita (keterbelakangan mental).

c. Cacat Ganda atau Cacat Fisik dan

Mental

Yaitu keadaan seseorang yang menyandang dua jenis kecacatan sekaligus. Apabila yang cacat adalah keduanya maka akan sangat mengganggu penyandang cacatnya.

Gangguan jiwa adalah bentuk dari manifestasi penyimpangan perilaku akibat distorsi emosi sehingga ditemukan tingkah laku dalam ketidak wajaran. Hal tersebut dapat terjadi karena semua fungsi kejiwaan menurun (Nasir, Abdul \& Muhith, 2011).

Gambaran Singkat Mengenai Orang Sakit Jiwa
Menurut artikel yang kamis akses dari laman Alodokter, platform informasi medis yang disediakan oleh tim dokter, mendefinisikan sakit jiwa adalah gangguan mental yang berdampak kepada mood, pola pikir, hingga tingkah laku secara umum. Seseorang disebut mengalami sakit jiwa, jika gejala yang dialami membuatnya tertekan dan tidak mampu melakukan aktivitas sehari-hari secara normal.

Lebih lanjut dijelaskan ciriciri orang yang mengalami sakit jiwa dapat berbeda-beda tergantung dari jenisnya. Namun pada umumnya, orang yang mengalami gangguan jiwa dapat dikenali dari beberapa gejala tertentu, seperti perubahan mood yang sangat drastis dari sangat sedih menjadi sangat gembira atau sebaliknya, merasa ketakutan yang secara berlebihan, menarik diri dari kehidupan sosial, kerap merasa sangat marah hingga suka melakukan kekerasan, serta mengalami delusional.

Masih bersumber dari artikel yang sama, ada banyak kondisi kesehatan yang dapat dikategorikan sebagai sakit jiwa. Tiap kelompok dapat terbagi lagi menjadi jenis-jenis yang lebih spesifik sebagai contoh antara lain: gangguan kecemasan, gangguan kepribadian, gangguan 
psikologis, gangguan pasca-trauma, dan gangguan disosiatif.

Sedangkan dari segi hukum, menurut UU No. 8 Tahun 2016 tentang Penyandang Disabilitas dijelaskan bahwa orang yang mempunyai keterbatasan atau gangguan mental (sakit jiwa) merupakan termasuk kategori penyandang disabilitas mental. Yang dimaksud dengan penyandang disabilitas menurut Pasal 1 angka 1 UU No. 8 Tahun 2016 adalah setiap orang yang mengalami keterbatasan fisik, intelektual, mental, dan/atau sensorik dalam jangka waktu lama yang dalam berinteraksi dengan lingkungan dapat mengalami hambatan dan kesulitan untuk berpartisipasi secara penuh dan efektif dengan warga negara lainnya berdasarkan kesamaan hak.

Jadi dengan berbagai pengertian diatas bisa disimpulkan bahwa yang dimaksud dengan "Penyandang Disabilitas Mental" adalah terganggunya fungsi pikir, emosi, dan perilaku, antara lain: psikososial di antaranya skizofrenia, bipolar, depresi, anxietas, dan gangguan kepribadian; dan disabilitas perkembangan yang berpengaruh pada kemampuan interaksi sosial di antaranya autis dan hiperaktif.
Untuk mempertegas posisi warga yang menggalami gangguan secara mental/jiwa dalam kedudukan hukum yang berkaitan dengan tanggung jawab dimuka hukum atau pengadilan, Pasal $433 \mathrm{KUH}$ Perdata juga memberikan definisi pada orang sakit jiwa, yaitu orang sakit jiwa atau sakit otaknya dikatakan berada di bawah pengampuan, berikut bunyi pasalnya:

Setiap orang dewasa, yang selalu berada dalam keadaan dungu, sakit otak atau mata gelap harus ditaruh di bawah pengampuan, pun jika ia kadang-kadang cakap mempergunakan pikirannya. Seseorang dewasa boleh juga ditaruh di bawah pengampuan karena keborosannya.

Jika mencermati bunyi Pasal KUH Perdata tersebut, pada dasarnya ada kondisi bagi orang dengan sakit jiwa atau gangguan jiwa untuk mendapat perlakuan khusus (pengampunan) atau pembebasan dan kondisi tersebut membuat dia bebas dari semua tanggung jawab didepan hukum.

\section{Apakah Orang Sakit Jiwa Berhak Memilih di Pemilu?}

Lalu ada pertanyan mengenai apakah penyandang disabilitas mental (sakit jiwa) berhak memilih di pemilu berdasarkan peraturan perundang- 
undangan yang mengatur proses penyelenggaraan pemilu?

Perlu dipahami bahwa UUD 1945 menjamin hak setiap orang atas pengakuan, jaminan, perlindungan, dan kepastian hukum yang adil serta perlakuan yang sama di hadapan hukum. Selain itu Pasal 43 UU No. 39 Tahun 1999 Tentang HAM mengatur hak warga negara untuk turut serta dalam pemerintahan, yakni:

1. Setiap warga negaraberhak untuk dipilih dan memilih dalam pemilihan umum berdasarkan persamaan hak melalui pemungutan suara yang langsung, umum, bebas, rahasia, jujur, dan adil sesuai dengan ketentuan peraturan perundangundangan.

2. Setiap warga negara berhak turut serta dalam pemerintahan dengan langsung atau dengan perantaraan wakil yang dipilihnya dengan bebas, menurut cara yang ditentukan dalam peraturan perundangundangan.

3. Setiap warga negara dapat diangkat dalam setiap jabatan pemerintahan.

Dari segi undang-undang lain, UU No. 36 Tahun 2009 Tentang Kesehatan Pasal 148 mengatur:

Penderita gangguan jiwa mempunyai hak yang sama sebagai warga negara.
1. Hak sebagaimana dimaksud pada ayat (1) meliputi persamaan perlakuan dalam setiap aspek kehidupan, kecuali peraturan perundang-undangan menyatakan lain.

Selain itu sebagai seorang penyandang disabilitas mental, Pasal $13 \mathrm{UU}$ No. 8 Tahun 2016 Tentang Penyandang Disabilitas juga mengatur hak-hak politik penyandang disabilitas antara lain:

a. memilih dan dipilih dalam jabatan publik;

b. menyalurkan aspirasi politik baik tertulis maupun lisan;

c. memilih partai politik dan/atau individu yang menjadi peserta dalam pemilihan umum;

d. membentuk, menjadi anggota, dan/atau pengurus organisasi masyarakat dan/atau partai politik;

e. membentuk dan bergabung dalam organisasi Penyandang Disabilitas dan untuk mewakili Penyandang Disabilitas pada tingkat lokal, nasional, dan internasional;

f. berperan serta secara aktif dalam sistem pemilihan umum pada semua tahap dan/atau bagian penyelenggaraannya;

g. memperoleh Aksesibilitas pada sarana dan prasarana penyelenggaraan pemilihan umum, pemilihan gubernur, 
bupati/walikota, dan pemilihan kepala desa atau nama lain; dan

h. memperoleh pendidikan politik.

Berkaitan dengan bolehkah penyandang disabilitas mental (orang sakit jiwa) memilih dalam pemilu, sepanjang penelusuran kami dalam peraturan perundang-undangan di bidang pemilu, tidak ada larangan yang secara eksplisit yang mengatur larangan bagi penyandang disabilitas mental untuk ikut serta memilih dalam pemilu. Jadi dapat disimpulkan bahwa pada dasarnya setiap warga negara dijamin haknya untuk dipilih dan memilih dalam pemilu termasuk penyandang disabilitas mental.

\section{PARTISIPASI PEMILIH DALAM PEMILU 2019}

Jika mencermati dari hasil lapangan dan data yang diperoleh dari perhitungan hasil suara, bahwa tingkat kehadiran pemilih dalam menggunakan hak suara dalam pemilu 2019 khususnya Pilpres adalah tercatat 135.106 pemilih menggunakan hak suara. Di banding dengan Data Pemilih Tetap (DPT) yaitu sebanyak 160.647 maka ada sebesar 84,10 $\%$ pemilih yang menggunakan haknya. Angka ini lebih tinggi dari target partisipasi nasional sebesar 73\%. Dan jika dibanding dengan penyelenggaraan pemilu sebelumnya serta Pilkada, angka ini juga cukup tinggi karena angka sebelumnya berkisar pada $67-78 \%$ saja.

Peningkatan angka partisipasi pemilih ini sebetulnya juga di sebabkan semakin diperbaikinya angka keakuratan DPT. Sebab kita tahu bahwa angka partisipasi itu muncul hanya berdasarkan perbandingan antara DPT dengan jumlah seluruh pemilih yang menggunakan hak suara nya pada hari H. Padahal kita tahu, bahwa pada periode sebelumnya angka jumlah DPT selalu menjadi persoalan. Di mana dalam data itu masih banyak yang ganda, tidak jelas orangnya, yang meninggal masih tercatat dan seterusnya. Sehingga ketika angka itu sebagai pembanding untuk menentukan angka partisipasi, akan ada bias sebetulnya.

Namun pada periode ini, KPU sepertinya ingin memperbaiki dan memastikan data pemilih valid dan akurat. Walaupun sebetulnya di lapangan masih ada beberapa temuan seperti yang peneliti temui, ada saja pemilih yang tidak tercatat (salah satunya petugas KPPS) padahal sudah ada beberapa tahap perbaikan, namun masih tertinggal. Kita meyakini bahwa data yang terakhir tersaji, adalah data yang semakin meminimalisir pemilih 
yang tertinggal. Sehingga pada akhirnya secara umum prosentasi pemilih menggunakan hak suaranya semakin meningkat.

Disisi lain, peningkatan partisipasi pemilih disebabkan faktor emosional pemilih khususnya dalam pemilihan Presiden dan Wakil Presiden 2019. Sentimen pribadi, menjadi faktor pemicu mereka secara sadar menggunakan suara untuk mendukung calon nya. Karena dengan dua calon yang maju bertarung, sebetulnya membuat kompetisi pemilihan jadi lebih hangat dan terbuka. Prosesproses kampanye yang dibumbui dengan berbagai branding dan pencitraan dengan narasi-narasi yang dibuat sedemikian rupa, mendorong persepsi pemilih sudah terblok pada penilaian pribadi atas masing-masing calon. Sehingga pada akhirnya animo ini mendorong mereka secara sadar untuk menggunakan hak pilihnya. Dan ini diperkuat dengan kondisi kultur masyarakat Amuntai yang agamis, sehingga mindset bahwa faktor agama dan segala elemen/atribut pelengkapnya menjadi nilai sacral yang mesti dijunjung dan dipatuhi. Stigma agama menjadi alat picu untuk mendorong sisi sentiment dan psikologis pemilih tadi. Makanya ini terbukti ketika pasangan No.02 unggul dengan perolehan suara 93.929 suara atas pasangan No. 01 yang memperoleh 34.535 suara. Atau perbandingan nya adalah 26,88 $\%$ dengan $73,12 \%$.

Ini sebetulnya agak sedikit kontra ketika kita membicarakan pemilihan legislatif yang pelaksanaannya berbarengan pada saat itu juga. Pada pemilihan legislatif lebih terkesan pemilih di mobilisasi dengan pendekatan material. Bukan pada kesadaran untuk menggunakan suara nya secara sukarela. Hal ini bisa dikonfirmasi ketika para pemilih ditanya bahwa mereka menunggu amplop dari caleg yang ingin mendapat suara nya.

\section{Partisipasi dan Hak Politik Kelompok Disabilitas}

Dari uraian sebelumnya sudah jelas kita menafsirkan bahwa hak warga Negara di jamin tanpa pengecualian, termasuk kelompok disabilitas. Oleha karenanya ketika dalam event Pemilu dalam konteks memilih pemimpin dan wakil rakyat yang akan mengisi posisi Eksekutif dan Legislatif, kelompok disabilitas juga memiliki hak suara.

Partisipasi Politik yang menurut McClosky dalam Budiardjo (2007:367) partisipasi politik adalah kegiatan-kegiatan sukarela dari warga masyarakat melalui 
dimana mereka mengambil bagian dalam proses pemilihan penguasa, dan secara langsung atau tidak langsung, dalam proses pembentukan kebijakan umum.

Sementara Menurut Samuel P. Huntington dan Joan M. Nelson dalam Budiardjo (2007:368) : Partisipasi politik adalah kegiatan warga negara yang bertindak sebagai pribadi-pribadi, yang dimaksud untuk mempengaruhi pembuatan keputusan oleh pemerintah. Partisipasi bisa bersifatindividual atau kolektif, terorganisir atau spontan, mantap atau sporadis, secara damai atau dengan kekerasan, legal atau ilegal, efektif atau tidak efektif.

Menurut Budiyanto (2007:19) Partisipasi politik adalah kegiatan seseorang atau sekelompok orang untuk ikut serta secara aktif dalam kehidupan politik, seperti memilih pemimpin negara atau upaya-upaya mempengaruhi kebijakan pemerintah.

\section{Menurut Surbakti (1992:142)} Partisipasi sebagai kegiatan dibedakan menjadi partisipasi aktif dan partisipasi pasif. Yang termasuk dalam kategori partisipasi aktif ialah mengajukan usul mengenai suatu kebijakan umum, mengajukan alternatif kebijakan umum yang berlainan dengan kebijakan yang dibuat pemerintah, mengajukan kritik dan perbaikan untuk meluruskan kebijakan, membayar pajak dan memilih pemimpin pemerintahan.

Dari berbagai definisi dan pengertian yang diungkapkan para ahli, bahwasanya pertisipasi dan hak pemilih menjadi sesuatu yang melekat pada indivu/pemilih yang sudah memenuhi syarat sesuai ketentuan. Tinggal apakah masyarakat pemilih tersebut akan menggunakan hak dan partisipasinya secara aktif.?

Mengutip dari laman WWW.Hukumonline.com, Hal senada juga disampaikan oleh Feri Amsari, Direktur Pusat Studi Konstitusi (PUSaKo) Fakultas Hukum Universitas Andalas, yang berpendapat bahwa sakit jiwa atau mental illness dan mental retardation adalah kondisi dimana seseorang memiliki keterhambatan kecerdasaran atau kesadaran. Jika dilihat dalam penyelenggaran pemilu, fenomena pemilih dengan kondisi mental illness dan retardation itu menjadi diskursus menarik dalam perkembangan pemilu. Lanjut menurut Feri, perkembangan hak pilih terus terjadi dan bukan tidak mungkin warga negara yang mengalami mental illness dan retardation dapat memperoleh hak pilihnya. Pada kondisi 
tertentu perlu dipahami bahwa tidak semua orang sakit jiwa tidak boleh memilih bahkan di Eropa ada orang sakit jiwa boleh memilih.

Mengingat kelompok masyarakat disabilitas adalah kelompok masyarakat yang memiliki kekhususan sendiri, terutama kelompok ODGJ maka keaktifan mereka dalam menggunakan hak politiknya, masih terbentur pada peraturan dan mekanisme tersendiri. Mereka perlu diberi ruang khusus dengan fasilitas yang sesuai dengan kondisi mereka.

Dalam pelaksanaan Pemilu 2019 bulan April yang lalu, dapat dilihat dari hasil Pleno Rekapitulasi Suara Pilpres, diperolah data dan gambaran terkait partisipasi penggunaan hak suara oleh kelompok Disabilitas, seperti tabel di bawah ini :

\begin{tabular}{|c|c|c|c|c|c|c|c|c|c|c|c|c|c|}
\hline \multirow{2}{*}{ No } & \multirow{2}{*}{\multicolumn{2}{|c|}{ Data Pemilih Disabilitas }} & \multicolumn{11}{|c|}{$\begin{array}{c}\text { RINCIAN } \\
\text { ( Kecamatan) }\end{array}$} \\
\hline & & & DP & BBR & SP & AS & AT & $\mathrm{AU}$ & BJG & $\mathrm{HG}$ & PMGR & ST & $\begin{array}{c}\text { JML } \\
\text { AKHIR }\end{array}$ \\
\hline \multirow{3}{*}{1.} & \multirow{3}{*}{$\begin{array}{l}\text { Jumlah Seluruh } \\
\text { Pemilih Disabilitas } \\
\text { Terdaftar Dalam } \\
\text { DPT, DPtb dan } \\
\text { DPK }\end{array}$} & LK & 14 & 32 & 44 & 36 & 48 & 39 & 27 & 25 & 7 & 46 & 318 \\
\hline & & PR & 18 & 31 & 33 & 35 & 52 & 45 & 23 & 29 & 4 & 38 & 308 \\
\hline & & JML & 32 & 63 & 77 & 71 & 100 & 84 & 50 & 54 & 11 & 84 & 626 \\
\hline \multirow[t]{3}{*}{2.} & \multirow{3}{*}{$\begin{array}{l}\text { Jumlah Seluruh } \\
\text { Pemilih Disabilitas } \\
\text { yang menggunakan } \\
\text { Hak Pilih }\end{array}$} & LK & 9 & 11 & 29 & 20 & 25 & 21 & 11 & 12 & 4 & 23 & 165 \\
\hline & & PR & 10 & 17 & 14 & 10 & 19 & 24 & 7 & 12 & 1 & 20 & 134 \\
\hline & & JML & 19 & 28 & 43 & 30 & 44 & 45 & 18 & 24 & 5 & 43 & 299 \\
\hline
\end{tabular}

Sumber : Di olah, KPU Kabupaten Hulu Sungai Utara 2019

Dari tabel diatas, angka kehadiran pemilih disabilitas dalam menggunakan hak suaranya hanya 47,76 \% dari DPT pemilih disabilitas yaitu sebanyak 299 pemilih menggunakan suara dari 626 pemilih disabilitas terdaftar dalam DPT. Dan angka ini pun disumbang oleh pemilih disabilitas fisik. Karena mereka lebih mudah secara teknis dilapangan untuk menggunakan hak suara.
Sementara disabilitas mental, masih belum maksimal terakomodir dalam proses pemilu ini. Karena faktor administasi di mana mereka juga harus memiliki E-KTP atau setidaknya Suket, dan itu pun harus sudah terekam datanya di Dukcapil, pada sisi lain pihak keluarga juga masih ada keengganan memfasilitasi proses itu karena faktor kerepotan yang muncul, penilaian masyarakat (malu) dan ke dokter jiwa ketika harus mendapat surat keterangan dokter. 
Inilah yang juga menjadi pertanyaan peneliti ketika ada keputusan oleh MK yang menyatakan bahwa boleh pakai Suket bagi masyarakat yang berhak memilih ikut menggunakan hak suaranya ketika mereka belum memiliki E-KTP. Tetapi untuk dapat Suket tetap perlu rekam data. Dan ketika ODGJ ini diharuskan juga ikut memilih tetapi mereka tidak rekam data, bagaimana mereka dapat ikut memilih? Apakah aturan dan keputusan KPU ini model "memaksa" tetapi pada satu sisi ada yang tidak siap? Jawaban pertanyaan inilah yang seperti dikatakan oleh Komisioner Komnas HAM Pusat Bapak Hairansyah, SH. MH, "ketika memang setiap pemilih harus terdaftar dan memiliki E-KTP atau Suket dan mereka sudah rekam data". Tetapi kata beliau "dalam Aspek HAM seharusnya hak memilih tidak ada rintangan dalam administrasi karena itu menjadi kewajiban Negara untuk memenuhi."

Walaupun kalau kita nilai angka itu terlihat kecil dalam bandingan DPT, namun jika skala adalah nasional maka akan terlihat jumlah angka pemilih ini juga cukup signifikan. Dan pada dasarnya secara substansi kita harus melihat, bahwa yang dikedepankan bukan semata-mata angka saja (kuantitas) tapi juga pada sisi kualitas penyelenggaraan pemilu yang benar-benar dari rakyat, oleh rakyat dan untuk rakyat. Di sinilah menjadi penting bagaimana segala hal yang berkaitan dengan proses dan tahapan memang benarbenar dapat diakses dan diikuti rakyat terutama pemilih secara aman, nyaman dan lancar.

\section{DILEMATIKA PELAKSANAAN HAK PILIH ODGJ}

Tidak bisa dipungkiri ketika KPU Pusat menyatakan bahwa kelompok pemilih ODGJ dapat menggunakan hak suaranya menimbulkan pro dan kontra. Bukan tanpa sebab reaksi masyarakat muncul, karena selama proses tahapan berjalan ada banyak kendala yang dihadapi KPU hingga KPUD dan penyelenggara di tingkat bawah. Jangan kan untuk memastikan bagaimana mengakomodir pelaksanaan pemilihan bagi ODGJ, untuk pemutakhiran data pemilih saja KPU butuh berkali-kali perbaikan. Dan fakta di lapangan hingga pelaksanaan pencoblosan hari $-\mathrm{H}$, masih ada saja warga yang tidak masuk dalam DPT. Padahal DPT sudah diperbaiki menjadi DPT, DPTb, DPK dan itu dilakukan sebanyak 3 kali pleno. Sehingga ketika muncul lagi ketentuan KPU yang mensyaratkan membolehkan ODGJ ikut memilih, timbul pertanyaan bagaimana mereka penyelenggara dapat 
memastikan prosesnya ketika hari $\mathrm{H}$ berjalan normal.

Dari berbagai kondisi yang dicermati selama pelaksanaan berlangsung, peneliti melihat dan menilai ada beberapa hal yang menjadi persoalan yang dihadapi di lapangan ketika kebijakan itu dibuat untuk dilaksanakan.

\section{- Malah Teknis/Prosedur}

Berdasarkan keterangan dari Ketua KPUD Hulu Sungai Utara, Ibu Rina Mei Saputri ketika di wawancara, bahwa memang tidak jelas arahan terkait teknis bagaimana pelaksanaan untuk mengakomodir para disabilitas (ODGJ) ketika nanti ikut dalam pemilihan. "Bimteks untuk kegiatan itu tidak ada." Jadi kami juga agak bingung," kata beliau.

Dengan kondisi demikian, akhirnya proses di lapangan hanya mengandalkan pengalaman dan upaya inisiatif personal dari masing-masing pihak. Jika mengacu pada peraturan PKPU No.11 tahun 2019 pasal (3) yang berbunyi Pemilih yang sedang terganggu jiwa/ingatannya sebagaimana dimaksud pada ayat
(2) huruf b, sehingga tidak memenuhi syarat sebagai Pemilih, harus dibuktikan dengan surat keterangan dokter. Ini pun teknis bagaimana proses dan prosedurnya tidak jelas. Ketika ini Cuma diterapkan ternyata persoalan untuk mengakomnodir pemilih ODGJ yang memiliki surat keterangan juga hampir tidak ada. Sehingga akhirnya hak suara pemilih disabilitas mental menjadi terbuang sia-sia.

Sehingga jika melihat dari tabel angka partisipasi pemilih disabilitas yang tercantum secara umum di Berita Acara hasil rekapitulasi suara, masih banyak yang tidak menggunakan hak suaranya. Dalam data itu tercatat hanya sebesar 47,76 \% atau sebanyak 299 pemilih menggunakan hak suara dari 626 pemilih dalam DPT. Ini pun hasil gabungan seluruh pemilih disabilitas, tanpa ada perincian lebih lanjut atas masing-masing kelompok disabilitas yang ada baik itu tuna daksa, tuna netra, tuna rungu, tuna grahita dan disabilitas lainnya. 
Hal dapat diartikan bahwa pesan yang ingin disampikan melalui keputusan dan aturan yang dibuat KPU, agar seluruh masyarakat terutama pemilih dapat aktif dalam pemilu secara khusus untuk pemilih disabilitas (ODGJ) tidak sesuai harapan. Karena belum dibarengi dengan tindak lanjut yang lebih kongkret secara teknis dan prosedur sehingga dapat mengakomodir pemilih khusus ini.

Jika pun ada disabilitas yang menggunakan hak suara, itu lebih banyak dilakukan oleh kelompok disabilitas fisik. Sementara disabilitas mental, masih belum maksimal terakomodir dalam proses pemilu ini. Karena faktor administasi di mana mereka juga harus memiliki E-KTP atau setidaknya Suket, dan itu pun harus sudah terekam datanya di Dukcapil, pada sisi lain pihak keluarga juga masih ada keengganan memfasilitasi proses itu karena faktor kerepotan yang muncul, penilaian masyarakat (malu) dan ke dokter jiwa ketika harus mendapat surat keterangan dokter.
- Kesiapan Penyelenggara Pemilu di Daerah

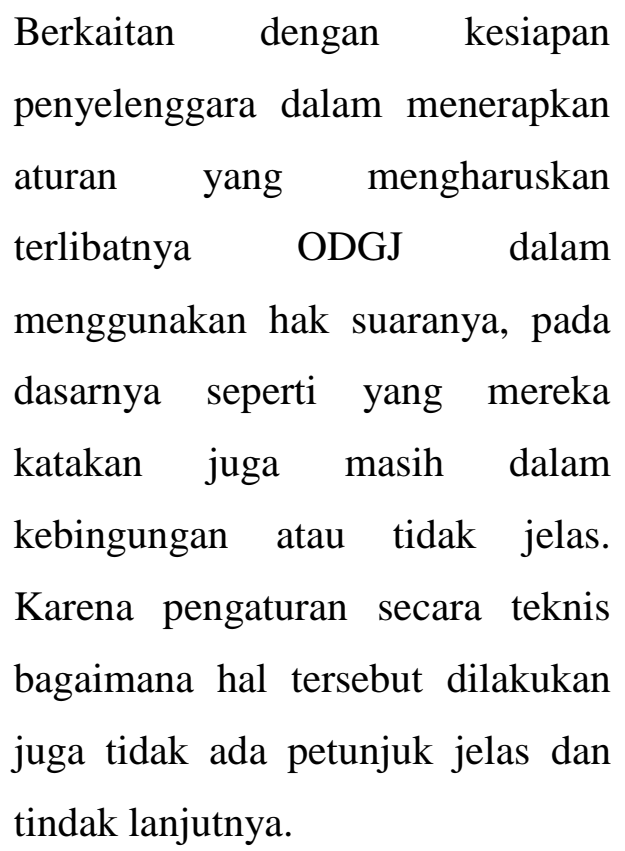

Sehingga pada akhirnya pada level penyelenggara di TPS, mereka melakukan proses berdasarkan inisiatif yang mereka pahami asal yang berhak memilih dari pemilih disabilitas atau ODGJ ini dapat ikut memilih dan terlaksana. Sehingga terkesan pemenuhan hak politik ODGJ terabaikan oleh pihak penyelenggara di bawah.

Dengan kondisi yang demikian, akhirnya menjadi pertanyaan apakah prinsip dan asas pemilu yang langsung, umum bebas dan rahasia serta jujur dan adil ini dapat diterapkan dengan benar jika kondisinya tidak berada dalam jaluar aturan yang seharusnya? 
Mengapa hal itu jadi pertanyaan, karena dengan beberapa kondisi pemilih disabilitas yang butuh perlakuan khusus terutama ODGJ akan dapat memberikan hak suara dengan rahasia? Jika misalnya pendampingan bukan dari keluarga terdekat? Pemilih ini cenderung diarahkan? Atau yang terjadi akibat tidak ingin repot dan adapat mengganggu situasi TPS, hak pemilih disabilitas ini di wakili oleh petugas KPPS?

Memang pada kenyataan nya ketika pelaksanaan hari-H pencoblosan, tidak terjadi kejadian yang dapat memicu protes atau kegaduhan ketika pemungutan suara berlangsung dan masyarakat yang lain juga tidak terlalu peduli bagaimana mekanisme dan prosedur sebetulnya atas hal tersebut, tetapi pada dasarnya tetap menjadi penting bagi petugas dilevel bawah (KPPS) untuk dibekali pengetahuan dan pemahaman terkait tata cara, aturan dan prosedur yang lebih baik agar penerapan hak asasi pemilih disabilitas ini terkhusus ODGJ benar-benar terakomodir dengan baik.

Setelah mencermati dari ulasan dan gambaran diatas, peneliti berusaha menjawab permasalahan dalam rumusan masalah diatas, bahwa bagaimana mendorong partisipasi politik pemilih bisa lebih meningkat dan bagaimana penerapan asas pemilu pada kelompok pemilih disabilitas terkhusus kelompok ODGJ, maka bisa dijelaskan sebagai berikut :

- Upaya untuk meningkatkan partisipasi pemilih dalam menggunakan hak suara bukan hanya sekedar "mengajak" pemilih datang ke TPS lalu mencoblos setelahnya itu selesai. Yang lebih utama adalah sebetulnya bahwa ada kesadaran publik bahwa memilih dan dipilih adalah Hak yang sudah melekat sebagai warga Negara dan telah diatur dalam berbagai regulasi atau aturan hukum. Penekanan lain bahwa Pemilu sebagai sarana politik untuk menentukan kepemimpinan bangsa menjadi media yang paling konstitusional untuk mengganti atau mempertahankan kepemimpinan yang sesuai dengan kehendak rakyat (pemilih).

Langkah yang dilakukan
penyelenggara dalam hal ini KPU dalam upaya meningkatkan partisipasi pemilih, sampai juga mengupayakan pemilih ODGJ agar dapat menggunakan suara, patutlah diapresiasi. Karena memang secara hukum, tidak ada larangan bagi ODGJ untuk menggunakan hak suaranya. Namun secara teknis dilapangan, sebagai penyelenggara KPU tidak memberikan arahan dan petunjuk dan jelas bagi penyelenggara di bawahnya 
agar pelaksanaan teknis dilapangan tidak menimbulkan masalah dan kendala.

Di luar konteks bahwa orang sakit jiwa ini merupakan orang yang di bawah pengampunan menurut hukum perdata, konstitusi sendiri pada dasarnya memberikan hak yang sama kepada orang yang memiliki penyakit jiwa untuk memilih. Bahkan dalam UU Pemilu sendiri tidak ada larangan yang secara eksplisit yang mengatur hal ini. Artinya orang sakit jiwa juga berhak menggunakan hak pilihnya. Tidak semua orang sakit jiwa tidak memiliki kesadaran untuk memilih. Tentu dengan catatan ada kondisi tertentu yang diperbolehkan untuk memilih. Namun yang penting bahwa penerapan asas pemilu yang langsung, umum, bebas, rahasia serta jujur dan adil itu juga dapat dirasakan oleh pemilih ODGJ. Jangan sampai hak mereka bisa digunakan namun hanya sekedar formalitas memilih tanpa ada kerahasiaan. Jangan sampai dengan adanya pemberian hak pilih pada warga negara dengan kondisi tertentu itu akan ada peluang untuk melakukan kecurangan dalam pemilu. Kecurangan itu merugikan hak pilih orang yang memiliki gangguan jiwa tersebut karena dianggap mudah dicurangi.

\section{PENUTUP}

\section{Kesimpulan}

Pemilu sebagai sarana politik warga Negara dalam menyalurkan hak politik dan suaranya seperti Negara Indonesia adalah merupakan agenda yang sudah berlangsung lama. Upaya untuk melakukan perbaikan dan peningkatan kualiatas penyelenggaraan terus dilakukan terutama juga dalam upaya untuk meningkatkan partisipasi pemilih. Berbagai kegiatan tahapan, agenda dan kegiatan dilakukan untuk itu.

Bahwa dalam pelaksanaan Pemilu 2019 ini, KPU lebih maksimal dalam meningkatkan partisipasi tersebut terlihat dalam mengakomodir setiap warga Negara yang berhak memilih melalui perbaikan DPT yang berkali-kali di plenokan. Adalah langkah untuk memastikan setiap warga yang Negara yang memenuhi syarat agar terdaftar dan dapat menggunakan hak pilihnya. Termasuk yang didorong KPU dan diakomodir untuk bisa berpartisipasi adalah kelompok disabilitas terkhusus ODGJ.

Sangat jelas dalam posisi hukum bahwa penyandang disabilitas mental adalah termasuk warga negara Indonesia (WNI) yang memiliki hak 
konstitusional yang sama. Dan itu termuat dalam berbagai aturan dan perangkat hukum Negara kita, terutama aturan tentang kepemiluan. Langkah KPU ini merupakan bentuk nyata dari realisasi jaminan hak politik yang setara bagi setiap warga negara sesuai dengan ketentuan dalam berbagai Undang-Undang termasuk UU No. 8 Tahun 2016 Tentang Penyandang Disabilitas, UU Pemilu, serta Konvensi PBB tentang Hak-Hak Penyandang Disabilitas yang telah diratifikasi oleh Indonesia melalui UU No.19 Tahun 2011 tentang Pengesahan Konvensi Mengenai Hak-Hak Penyandang Disabilitas.

Namun dalam praktek pelaksanaan di lapangan, masih ditemukan bahwa pelibatan kelompok disabilitas ini belum maksimal. Ini terlihat dari berita acara hasil rekapitulasi suara, bahwa tingkat partisipasi pemilih disabilitas masih kurang yaitu angka kehadiran pemilih disabilitas dalam menggunakan hak suaranya hanya $47,76 \%$ dari DPT pemilih disabilitas yaitu sebanyak 299 pemilih menggunakan suara dari 626 pemilih disabilitas terdaftar dalam DPT. Hal ini perlu menjadi catatan kedepan agar pelibatan kelompok disabilitas bisa lebih maksimal. Terutama juga kelompok disabilitas mental (ODGJ). Karena di lapangan yang terjadi kelompok ini tidak atau belum secara aktif terlibat. Selain karena faktor ketidakjelasan mekanisme bagaimana mengakomodir pelaksanaan teknis dilapangan, dukungan keluarga untuk mendorong keaktifan mereka juga kurang. Inilah juga pekerjaan bersama, bagaimana sebetulnya mendorong partisipasi itu bukan hanya di ukur hasilnya dari perbandingan DPT dan orang yang datang ke TPS menggunakan hak suaranya, tetapi membangun kesadaran bahwa Pemilu sebagai sarana politik untuk menentukan kepemimpinan bangsa menjadi media yang paling konstitusional untuk mengganti atau mempertahankan kepemimpinan yang sesuai dengan kehendak rakyat (pemilih).

Kemudian luar konteks bahwa orang sakit jiwa ini merupakan orang yang di bawah pengampunan menurut hukum perdata, konstitusi sendiri pada dasarnya memberikan hak yang sama kepada orang yang memiliki penyakit jiwa untuk memilih. Bahkan dalam UU Pemilu sendiri tidak ada larangan yang secara eksplisit yang mengatur hal ini. Artinya orang sakit jiwa juga berhak menggunakan hak pilihnya. Tidak semua orang sakit jiwa tidak memiliki kesadaran untuk memilih. Tentu dengan catatan ada kondisi tertentu yang diperbolehkan untuk memilih. Namun yang penting bahwa penerapan asas pemilu yang langsung, umum, bebas, rahasia serta jujur dan adil itu juga dapat dirasakan oleh pemilih ODGJ. Jangan 
sampai hak mereka bisa digunakan namun hanya sekedar formalitas memilih tanpa ada kerahasiaan atau malah dimanipulasi. Jangan sampai dengan adanya pemberian hak pilih pada warga negara dengan kondisi tertentu ini, akan ada peluang untuk melakukan kecurangan dalam pemilu. Kecurangan itu merugikan hak pilih orang yang memiliki gangguan jiwa tersebut karena dianggap mudah dicurangi.

\section{Saran}

Bahwa dalam upaya lebih memaksimalkan dan memastikan partisipasi pemilih terutama kelompok disabilitas hendaknya KPU menyiapkan kebijakan tambahan yang mendukung penyandang disabilitas terutama disabilitas mental (ODGJ) untuk ikut menggunakan hak pilihnya lewat koordinasi dengan Kementerian Sosial, Kementerian Kesehatan dan Pemerintah Daerah untuk memberikan dukungan dan fasilitas yang dibutuhkan, agar para penyandang disabilitas mental yang didaftar dapat menggunakan hak pilihnya. Dan yang terutama juga melakukan pendekatan dengan keluarga pemilih disabilitas ini, agar mereka juga memiliki pemahaman, pengetahuan serta dapat ikut aktif mendorong keterlibatan kelompok disabilitas mental ini.
KPU agar selalu melakukan sosialisasi dan edukasi kepada masyarakat, tim sukses para calon Presiden dan Wakil Presiden, Partai Politik peserta Pemilu, internal KPU dan penyelenggara dibawahnya, serta keluarga penyandang disabilitas terkait dengan hak politik penyandang disabilitas, khususnya penyandang disabilitas mental.

\section{DAFTAR PUSTAKA}

Bochel, Bugh. 2015. Political Literacy. (onlen), ( http://www.google.com,diakses Februari 2019)

Fathurrahman, Deden dan Sobari, Wawan. 2004. Pengantar Ilmu Politik. UMM Press. Malang

Kariada,I made dkk.2015.Fenomena Melek Politik masyarakat Klungkung Pada Pemilu 2014 dan Pemilukada 2012. Fisip Univ. UDAYANA dan KPUD KLUNGKUNG

Surbakti, Ramlan.1999. Memahami Ilmu Politik. Grasindo. Jakarta

Pito, Andrianus dkk.2006. Mengenal Teori-Teori Politik. Nuansa, Bandung Budi Lesmana | Penerapan Aspek .... | 41 
Suryadi, Budi.2008. Kerangka Analisis

Sistem Politik Indonesia. Scripta

Cendekia, Banjarbaru

Hurairah, Abu.2008. Pengorganisasian dan

Pengembangan Masyarakat: Model

dan Strategi Pembangunan Berbasis

Kerakyatan. HUMANIORA, Bandung

Sarman, Mukhtar.2002. MPS Untuk

Mahasiswa.Yasiba. Banjarbaru

Sugiyono,2009. Metode Kuantitatif,

Kualitatif dan $R \& D$. Alfabeta, Bandung

Wahyu dkk.2007. Pedoman Penulisan

Karya Ilmiah. FKIP Unlam. Banjarmasin

Undang-Undang Dasar 1945

Kitab Undang-Undang Hukum Perdata

UU No.39 Tahun 1999 Tentang Hak Asasi

Manusia

UU No. 36 Tahun 2009 Tentang

Kesehatan

UU No. 19 Tahun 2011 Tentang

Pengesahan Convention on the

Rights of Persons with Disabilities

(Konvensi mengenai Hak-hak

Penyandang Disabilitas)

UU No. 8 Tahun 2016 Tentang

Penyandang Disabilitas

UU No. 7 Tahun 2017 Tentang Pemilihan

Umum

PKPU No. 11 Tahun 2019 Tentang

Perubahan Kedua Atas Peraturan Komisi

Pemilihan Umum Nomor 11 Tahun 2018
Tentang Penyusunan Daftar Pemilih Di

Dalam Negeri Dalam Penyelenggaraan Pemilihan Umum

Komisi Pemilihan Umum Kabupaten Hulu Sungai Utara, 2019

Dinas Sosial Kabupaten Hulu Sungai Utara, 2019

Dinas Kependudukan Dan Catatan Sipil Kabupaten Hulu Sungai Utara, 2019

Bapak H. Hairansyah, SH. MH. Komisioner Komnas HAM Pusat, Jakarta 2019

Dumilah

Ayuningtyas1,

Misnaniarti,21Marisa Rayhani1 p-ISSN 2086-6380 Jurnal Ilmu Kesehatan Masyarakat, Maret 2018, http://www.jikm.unsri.ac.id/index.php/jik m Maret 2018 ANALISIS SITUASI KESEHATAN MENTAL PADA MASYARAKAT DI INDONESIA DAN STRATEGI PENANGGULANGANNYA (di Akses Februari 2019)

Artikel ini diambil dari : www.depkes.go.id STOP STIGMA DAN DISKRIMINASI TERHADAP ORANG DENGAN GANGGUAN JIWA (ODGJ) DIPUBLIKASIKAN PADA : JUMAT, 10 OKTOBER 2014 (Dia akses Februari 2019). 
https://www.hukumonline.com/klinik/detai

1/ulasan/lt5bf7a73cc679f/apakah-orang-

sakit-jiwa-berhak-memilih-dalam-pemilu 